\title{
1 Grid box-level evaluation of IMERG over Brazil at various space and time
}

2 scales

3 André N. Gadelhaa ${ }^{\mathrm{a}, *}$, Victor Hugo R. Coelho ${ }^{\mathrm{a},{ }^{*}}$, Alexandre C. Xavier ${ }^{\mathrm{b}}$, Luís Romero Barbosa ${ }^{\mathrm{a}, \mathrm{c}}$, Davi C. D.

4 Melo ${ }^{\mathrm{d}, \mathrm{e}}$, Yunqing Xuan ${ }^{\mathrm{f}}$, George J. Huffman, Walt A. Petersen ${ }^{\mathrm{h}}$, Cristiano N. Almeida ${ }^{\mathrm{a}}$

5

6 a Department of Civil and Environmental Engineering, Federal University of Paraíba, João Pessoa, PB 58051-

$7 \quad 900$, Brazil

$8 \quad$ b Department of Rural Engineering, Federal University of Espírito Santo, Alegre, ES 29500-000, Brazil

$9 \quad{ }^{\mathrm{c}}$ Institute of Earth and Environmental Science, University of Potsdam, Potsdam, BB 14476, Germany

$10{ }^{\mathrm{d}}$ Department of Soils and Rural Engineering, Federal University of Paraíba, Areia, PB 58397-000, Brazil

$11{ }^{\mathrm{e}}$ Department Hydraulics and Sanitary Engineering, University of São Paulo, São Carlos, SP 13566-590, Brazil

$12 \quad{ }^{\mathrm{f}}$ College of Engineering, Swansea University, Swansea, SA1 8EN, UK

13 g NASA Goddard Space Flight Center, Greenbelt, MD 20771, USA

$14 \quad{ }^{\mathrm{h}}$ NASA Marshall Space Flight Center, Huntsville, AL 35805, USA

16 * Corresponding authors. Tel.: +55-83-3216-7684.

17 E-mail addresses: andregadelha5@hotmail.com (A.N. Gadelha), victor-coelho@hotmail.com (V.H.R. Coelho),

18 alexandre.xavier@ufes.br (A.C. Xavier), luisromero.eng@gmail.com (L.R. Barbosa), melo.dcd@gmail.com

19 (D.C.D. Melo), y.xuan@swansea.ac.uk (Y. Xuan), george.j.huffman@nasa.gov (G.J. Huffman),

20 walt.petersen@nasa.gov (W.A. Peterson), almeida74br@yahoo.com.br (C.N. Almeida).

ABSTRACT: Rainfall data from the Global Precipitation Measurement (GPM) mission provide a new source of information with high spatiotemporal resolution that overcomes the limitations of ground-based rainfall information worldwide. This study evaluates the performance of the Integrated Multi-satellitE Retrievals for GPM (IMERG) Final Run product over Brazil by means of multi-temporal and -spatial analyses. The assessment of the IMERG Final Run product is based on six statistics obtained for the period between January- 
estimates against a ground-based gridded rainfall product created using daily records from 4,911 rain gauges distributed throughout Brazil. Overall, the results show that the IMERG product can effectively capture the spatial patterns of rainfall across Brazil. However, the IMERG product presents a slight tendency in overestimating the ground-based rainfall at all timescales. Furthermore, the performance of the satellite varies throughout the regions. The higher errors and biases are found in the North and Central-West regions, but the low density of rain gauges in those regions can be a source of large deviations between IMERG estimates and observed data. As well, a large underestimation of the IMERG data is evidenced along the coastal zone of the Northeast region, probably due to the inability of the passive microwave and infrared sensors to detect warmrain processes over land. This study shows that the IMERG product can be a good source of rainfall data to complement the ground precipitation measurements in most of Brazil, although some uncertainties are found and need to be further studied.

Keywords: Gridded rainfall, Global Precipitation Measurement, Final Run, Performance

\section{Introduction}

Rainfall plays an important role in the water balance, as it is the main input into the hydrological system (Kidd and Huffman, 2011; Mahmoud et al., 2018; Schneider et al., 2016). Given its spatial and temporal variability, dense daily or sub-daily observations are required to understand specific hydrological processes (Kann et al., 2015; Kidd et al., 2017; McMillan et al., 2011; Meng et al., 2014). However, obtaining a consistent and continuous ground-based rainfall dataset with an adequate spatiotemporal resolution for such purposes remains a challenge worldwide, mainly because of the costs of operation and maintenance of the rain gauge monitoring network (Terink et al., 2018). Currently, the ground-based rainfall monitoring network in Brazil has approximately 11,820 rain gauges, resulting in an average density of one gauge per $720 \mathrm{~km}^{2}$, which is below the threshold of one gauge per $575 \mathrm{~km}^{2}$ recommended by the World Meteorological Organization (WMO) for the interior plane and undulating areas (WMO, 1994). However, the gauges are non-uniformly distributed with some regions in Brazil, such as the Southeast, having densities much higher than the threshold, reaching one gauge per $115 \mathrm{~km}^{2}$. Moreover, rain gauges with uninterrupted data in Brazil are few and the rainfall time series often contain temporal gaps. The lack of in-situ rainfall data is more acute in the Northern (which includes the 
Amazon rainforest) and Central regions of the country, leading to an insufficient characterisation of these regions (Buarque et al., 2011; Collischonn et al., 2008; Curtarelli et al., 2014; Delahaye et al., 2015).

Precipitation observations by alternative methods such as multiple satellite sensors have become a viable solution in the past few decades to overcome the limitations of ground-based data (Hobouchian et al., 2017; Levizzani et al., 2018; O and Kirstetter, 2018). Remotely sensed data can offer global information about precipitation with a range of required spatial and temporal resolutions. Furthermore, many remote sensing products related to rainfall are freely available for the end users (Mahmoud et al., 2018; Skofronick-Jackson et al., 2018; Tang et al., 2016a). One of the first dedicated and most important satellites for this purposes was the Tropical Rainfall Measuring Mission (TRMM), launched in 1997. It was a joint project between NASA (National Aeronautics and Space Administration) and JAXA (Japanese Aerospace Agency) to observe rainfall in the latitude band $50^{\circ}$ North to $50^{\circ}$ South (Huffman et al., 2007). TRMM provided products with a variety of spatial $\left(0.25^{\circ}\right.$ to $\left.5^{\circ}\right)$ and temporal (3-hour to 1-month) resolutions. In the past few years, many studies used the TRMM Multi-satellite Precipitation Analysis (TMPA) for various purposes in Brazil such as hydrological modelling due to the low density and intermittency of rain gauges in some river basins (e.g. Coelho et al., 2017; Collischonn et al., 2008; De Paiva et al., 2013; Falck et al., 2015; Melo et al., 2016). Many other studies worldwide were also carried out using the TMPA (including Baik and Choi, 2015; Fang et al., 2013; Naumann et al., 2012; Pombo and de Oliveira, 2015; Yang and Nesbitt, 2014). However, some studies highlighted the need to assess the accuracy of the TMPA by comparison with ground-based data on a regional basis. For example, Melo et al. (2015) evaluated the TMPA over Brazil using a 14-year time series for uncertainties in daily and monthly estimates.

Like TRMM, the Global Precipitation Measurement (GPM) mission is also a joint project led by NASA and JAXA; the GPM Core Observatory launched in February 2014. GPM is the successor to TRMM, providing rainfall and snow information globally as contained in the Integrated Multi-satellitE Retrievals for GPM (IMERG) products at $0.1^{\circ} \times 0.1^{\circ}$ (spatial) and half-hour (temporal) resolutions (Hou et al., 2014; Liu et al., 2017; Skofronick-Jackson et al., 2017). The IMERG algorithm incorporates microwave and infrared estimates from the GPM constellation, gauge observations, and other ancillary (Huffman et al., 2017a). Currently, there are three IMERG products available, namely: Early Run, Late Run, and Final Run. The Early and Late Run are near-real-time products available from 4 to $12 \mathrm{~h}$ after the observation, both being more suitable 
for time-sensitive applications. On the other hand, the Final Run product is available 3.5 months after the observation, which allows it to incorporate a surface gauge analysis from the Global Precipitation Climatology Centre (GPCC) to improve the satellite estimations. As such, the Final Run is the most suitable product for hydrological modelling purposes (Tang et al., 2016b).

The GPM opens up new opportunities for hydrological investigations, particularly in ungauged areas (Asong et al., 2017). However, the performance of the GPM products needs to be critically evaluated in different regions of the world as sources of information for both end users and data producers (Prakash et al., 2018). Several recent studies evaluated different IMERG products in complex areas under distinct climatic and geographic aspects worldwide by using ground-based data and/or comparisons with other satellite products such as TMPA (Anjum et al., 2018; Asong et al., 2017; Beria et al., 2017; Dezfuli et al., 2017; Gebregiorgis et al., 2018; Lelis et al., 2018; Mahmoud et al., 2018; Mayor et al., 2017; Mitra et al., 2018; Muhammad et al., 2018; O and Kirstetter, 2018; Oliveira et al., 2018; Prakash et al., 2018, 2016; Satgé et al., 2017; Sungmin et al., 2017; Tan et al., 2017; Tan and Duan, 2017; Tan and Santo, 2018; Tang et al., 2016a, 2016b; Wang et al., 2017; Zhang et al., 2018). Most of the aforementioned studies showed good agreement of the IMERG products with the gauge, radar, and TMPA data. However, other studies found the same or less accuracy for the IMERG products compared to those from TMPA (Satgé et al., 2017). Some studies mentioned above were carried out at country-wide scale. Table 1 provides a tabular literature review which shows these relevant country-scale studies evaluating the performance of IMERG products, including those done in Brazil. It is the case that countries such as Brazil and China encompass different climate zones and rainfall patterns due to their vast territories. Consequently, studies carried out in these countries may be able to provide more detailed and critical analyses of the IMERG products.

\section{INSERT TABLE 1}

Table 1 Summary of relevant studies that evaluated the IMERG products at country-wide scale in relation to the proposed study.

As IMERG products have only become available recently, the number of studies carried out in Brazil from local-to national-scales is still very small. To our knowledge, only four studies checked the quality of the IMERG products (e.g. Lelis et al., 2018; Oliveira et al., 2018, 2016; Rozante et al., 2018), which are 
significantly fewer than those that evaluated the TRMM products. For instance, Oliveira et al. (2016) used ground-based radar observations to evaluate the rainfall variations of the IMERG Final Run Version 04 product over an area of the Brazilian Amazon rainforest. They observed a satisfactory agreement between the groundbased and the satellite data during the period analysed (from March to September 2014), but IMERG Final overestimated the heavier rainfall rates during the wet season. Lelis et al. (2018) analysed the one-year performance of the IMERG product by using rain gauges data for the eastern region of São Paulo State, Brazil. They concluded that the IMERG product generally overestimated over this region. The only national-scale assessment was carried out by Rozante et al. (2018), using around 3,400 rain gauges distributed over Brazil. They analysed whether the daily IMERG data can properly replace the daily TMPA data. However, they considered as a reference for the analyses of both products the coarse spatial resolution $\left(0.25^{\circ}\right)$ of the TMPA. Moreover, they based their studies in a point-to-cell perspective, i.e. without a spatial analysis and considering only 1,779 cells of the IMERG product among the more than 70,000 available for the Brazilian territory. Clearly, the validation of satellite rainfall data based on a point-to-cell analysis has some limitations, as the gauge stations provide point measurements observed over a continuous period of time, whereas precipitation from satellite observation is an average within the grid cells (Cohen Liechti et al., 2012; Jesus et al., 2015; Toté et al., 2015; Zad et al., 2018). Consequently, the comparison suffers from scale mismatch issues and other validation methods are needed to improve the analyses and overcome this problem (Guo and Liu, 2016).

Considering the limitations of the previous studies assessing the IMERG products in Brazil, our aim is to expand the analyses of the IMERG Final Run product across the Brazilian territory, as follows: (1) using a grid box approach based on a gridded observed rainfall product, (2) including spatially varying analyses, and (3) encompassing other variables in the evaluation process such as climate, topography, and density of observed data used in the analyses. The IMERG product was compared with a large amount of daily ground-based measurements distributed over grids covering the country, with grid boxes matching the IMERG cells. We addressed the following questions in this study: (a) Can the IMERG product be used as a source of rainfall data over Brazil? (b) How does the quality of the IMERG product vary spatially? (c) Are the annual and monthly IMERG rainfall estimates more accurate than daily estimates? (d) What analysed variables have more influence on the performance of the IMERG product? In the end, this study intends to provide insights for further applications of the IMERG Final Run product in Brazil at daily, monthly, and annual scales. 
This study was carried out for the whole Brazil, which covers approximately $8.5 \mathrm{M} \mathrm{km}^{2}$ between the coordinates $5^{\circ} 16^{\prime} \mathrm{N}-33^{\circ} 45^{\prime} \mathrm{S}$ and $34^{\circ} 47^{\prime} \mathrm{W}-73^{\circ} 59^{\prime} \mathrm{W}$ (Fig. 1). Brazil is the largest country in Latin America and the fifth-largest country in the world in area. The Brazilian territory has five official geographical regions, namely: North (N), Northeast (NE), Central-west (CW), Southeast (SE), and South (S). These regions generally correspond to the spatial variations in the long-term mean annual rainfall in Brazil. Region N, where the Amazon rainforest is located, is characterised by prevailing convective rainfall that can be higher than 2,000

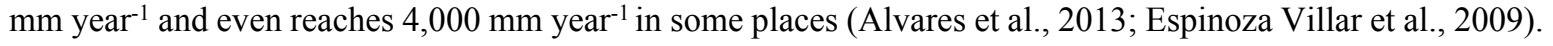
In contrast, most of region $\mathrm{NE}$ is characterised by a semi-arid climate in the inland area, with rainfall ranging from 380 to $700 \mathrm{~mm}_{\text {year }}{ }^{-1}$ (Alvares et al., 2013). However, along the first $100 \mathrm{~km}$ of the Atlantic coastal zone of NE, the rainfall can be as high as 1,500 $\mathrm{mm}$ year ${ }^{-1}$ (Kousky, 1979). The annual rainfall variations are similar in both regions $\mathrm{SE}$ and $\mathrm{CW}$, with values ranging from 1,000 to $2,000 \mathrm{~mm}$ and concentrated during the austral summer (Melo et al., 2015). On the other hand, the rainfall is more spatially uniform throughout the year in region S, ranging from 1,200 to 2,000 $\mathrm{mm}$ (Nery and Carfan, 2014). According to Alvares et al. (2013), Brazil has twelve different Koppen's climate types divided into three zones: Tropical (Zone A), Semiarid (Zone B), and Humid Subtropical (Zone C). The mean annual air temperature ranges from less than $10^{\circ} \mathrm{C}$ to greater than $26^{\circ} \mathrm{C}$. Besides Brazil as a whole, five different subareas with the same size $\left(1.9^{\circ} \times 1.2^{\circ}\right)$ were also selected to be individually evaluated in this study to check the quality of the IMERG data in small areas with high density of rain gauges (Fig. 1b). Each subarea is located in one of the five official geographical regions and represents different climate zones and/or annual average rainfall depths. Only subarea 2 is meridionally oriented in order to be confined to the Dry Zone and to cover as many rain gauges as possible. Fig. S1 shows the long-term monthly average rainfall obtained from rain gauges within the five selected subareas.

\section{INSERT FIG. 1}

Fig. 1 (a) Number and density of rain gauges used as a reference in the study. (b) Köppen's climate classification map for Brazil according to Alvares et al. (2013) and selected subareas. Spatial distributions of the annual 
rainfall (mm) for 2016 obtained from (c) rain gauges and (d) the IMERG-V05 Final product. The climatic symbols A, B, and C stand for Tropical, Dry, and Humid Subtropical, respectively.

\subsection{Rain gauge data}

This study used daily rainfall data from 4,911 rain gauges distributed over Brazil (Fig. 1). The groundbased data for 2016 were acquired from rain gauges that are operated by the Brazilian National Water Agency (ANA), Brazilian National Institute of Meteorology (INMET), and sixteen regional water agencies. The Angular Distance Weighting (ADW) interpolation method was used to produce a daily gridded observed rainfall data matching the $0.1^{\circ} \times 0.1^{\circ}$ IMERG grid (Hofstra and New, 2009; New et al., 2000; Xavier et al., 2016). Following the recommendation by Xavier et al. (2016), the weighting means data from the five available surrounding stations were used when applying the ADW method to perform the point-to-grid conversion. The weights for each station were defined by two components: (1) the weight due to the distance from the grid point to the rain gauge, calculated by the correlation decay distance (CDD) and (2) the weight of each station due to its isolation. Detailed information of the interpolation method can be found in Xavier et al. (2016). The gauge data were quality checked for extreme daily values equal to or higher than $450 \mathrm{~mm}$. The missing data throughout the year 2016 represents $\sim 10 \%$ of the total dataset recorded in the rain gauges. Gauges with missing data for a specific day were excluded from the interpolation to generate the gridded rainfall product for that day. Hence, the number of rain gauges changed over the study period, ranging from 2,975 to 3,739 for each day. The daily data were then accumulated to produce the monthly and annual information.

\subsection{IMERG data}

The IMERG dataset evaluated in this study is the Final Run product at the native $0.1^{\circ} \times 0.1^{\circ}$ (spatial) and half-hour (temporal) resolution; Version 05 (V05) of the Goddard Profiling Algorithm (GPROF V05) provides precipitation estimates from all microwave sensors onboard the GPM constellation. The main changes between the oldest and newest versions of the IMERG products are summarised by Huffman et al. (2017b). For instance, the IMERG-V05 improved the gauge error estimates to provide proper weighting of monthly gauge and satellite-only estimates. Also, the IMERG-V05 product added the Quality Index for all half-hour and monthly products. The IMERG-V05 Final Run product also uses the GPCC analysis of global ground-based 
monthly data from the Global Telecommunication System (GTS) and other sources, which is composed of 7,000 stations distributed around the world. This study compared gauge and satellite-based data independently by choosing ground-based stations not used by GTS. The comparisons between the IMERG-V05 and rain gauge datasets were performed in this study at daily, monthly, and annual scales. Therefore, we aggregated the 30minute IMERG-V05 data to match the daily information of the ground-based data, which is collected at 9:00 a.m. local time. The IMERG-V05 data were then accumulated between 9:00 a.m. (local time) and the subsequent 24 hours. Similar to the rain gauge data, the daily IMERG-V05 information was monthly and annually accumulated.

\subsection{Evaluation procedures}

Four evaluation procedures were performed to analyse the IMERG-V05 product over the Brazilian territory, so-called: (i) grid-scale, (ii) national-scale, (iii) subarea, and (iv) categorical analysis. The grid-scale comparison was carried out using the observed rainfall dataset and the IMERG-V05 product to evaluate the spatial behaviour of the satellite data. The national-scale analysis was performed to asses the satellite product over large areas comparing the national areal average of both ground-based and IMERG-V05 data. The subarea analysis consisted of computing the metrics of average values within each subarea defined in the study area section (see Fig. 1b). This analysis intends to assess how the IMERG-V05 performs in areas with a high density of gauges in each Brazilian region. The categorical analysis was carried out to better understand the spatial daily agreement between IMERG-V05 and observed rainfall data, based on the influence of climate, topography, and gauge density. The comparisons between the IMERG-V05 and rain gauge datasets were performed in this study at daily, monthly, and annual scales.

\subsection{Metrics}

Six statistical metrics divided into three main groups were used to assess the quality of the IMERGV05 product. Considering the temporal resolution of the rain gauge network, the threshold for all daily metric analyses was set to $0.1 \mathrm{~mm}$. Thus, all IMERG-V05 and/or rain gauge data with daily values below $0.1 \mathrm{~mm}$ were treated as zero. However, for the monthly and annual analyses, this threshold was not applied because it is of no physical sense. The first group of metrics is related to comparison of detecting the observed rainfall events, 
218 V05 detects and there are ground-based rainfall events; (ii) false alarm ratio (FAR), which gives the fraction of 219 events estimated by IMERG-V05 which are not detected in the surface data; and (iii) critical success index 220 (CSI), which combines the characteristics of false alarms and missed events:

$221 \quad P O D=\frac{a}{a+c}$

222

$\mathrm{FAR}=\frac{\mathrm{b}}{\mathrm{a}+\mathrm{b}}$

$223 \quad$ CSI $=\frac{a}{a+b+c}$

224 where a is the rainfall observed by the rain gauge and IMERG-V05 simultaneously, b is the rainfall observed 225 by the IMERG-V05 but not observed by the rain gauge, and $\mathrm{c}$ is the rainfall observed by the rain gauges which

226

$237 \quad$ RMSE $=\sqrt{\frac{1}{N} \sum_{i=1}^{n}\left(E_{i}-0_{1}\right)^{2}}$

$$
\mathrm{ME}=\frac{1}{\mathrm{~N}} \sum_{\mathrm{n}=1}^{1}\left(\mathrm{E}_{\mathrm{i}}-\mathrm{O}_{\mathrm{i}}\right)
$$

INSERT TABLE 2

Table 2 Definition of rainy and non-rainy days for IMERG-V05 and observed data. with the rain gauge data. It includes: (i) the mean error (ME), which represents the average magnitude of the satellite error, and (ii) the root mean square error (RMSE), which gives the sample standard deviation of the differences between the IMERG-V05 product and the observed rainfall:

where $\mathrm{O}$ is the observed rainfall $(\mathrm{mm}), \mathrm{E}$ is the IMERG-V05 estimated rainfall $(\mathrm{mm}), \mathrm{i}$ is the index of the number of pairs, and $\mathrm{n}$ is the total number of compared pairs. Both ME and RMSE measure the accuracy of the IMERG-V05 product, so values close to zero indicate smaller errors. However, the ME gives an overall 241 indicator of the bias (positive or negative), with the disadvantage that the positive and negative errors can cancel each other. Hence, sometimes a small ME does not means minor errors. The relative errors for both ME and 
RMSE metrics were also computed to improve the interpretation of data (see the supplementary material for more details).

The third group describes the agreement between IMERG-V05 estimates and ground-based data, which only includes the correlation coefficient (CC):

$$
C C=\frac{\frac{1}{n} \sum_{n+1}^{N}\left(O_{i}-\overline{0}\right)\left(E_{i}-\bar{E}\right)}{\sigma_{0} \sigma_{E}}
$$

where $\overline{\mathrm{O}}$ is the average observed rainfall values $(\mathrm{mm}), \overline{\mathrm{E}}$ is the average estimated rainfall values (mm), and $\sigma$ is the standard deviation ( $\mathrm{mm}$ ). The $\mathrm{CC}$ ranges from +1 to -1 , with the extremes representing total positive and total negative linear correlation, respectively.

\section{Results and discussion}

\subsection{Grid-scale evaluation}

In this analysis, the IMERG-V05 data was evaluated against the observed rainfall on the native $0.1^{\circ} \mathrm{x}$ $0.1^{\circ}$ IMERG grid. The spatial distributions of POD and CSI suggest a good agreement of the IMERG-V05 in detecting daily rainfall events in most parts of Brazil, with values generally higher than 0.6 for both metrics

(Fig. 2). The exception is along the eastern coast of the Brazilian NE, with many cells presenting values lower than 0.45 for both analysed metrics. The poor POD over coastal areas has also been observed in other studies of IMERG (e.g. Asong et al., 2017; Caracciolo et al., 2018). The FAR measures show that the IMERG-V05 product exhibited low false alarms at a daily scale, except for the central part of the NE along the Brazilian driest zone. This effect was probably caused by the low number of rainy days during the study period, as also noticed by Prakash et al. (2018) over southeast peninsular India due to the rain-shadow effects.

The spatial distribution of daily CC shows a good agreement of the IMERG-V05 product with the observed gridded data, wherein most cells presented values equal to or higher than 0.7 (Fig. 2d). The good agreement is more noticeable in the regions $\mathrm{S}, \mathrm{SE}$, and part of the NE. The exception in the region NE was observed along the Atlantic coastal zone, with $\mathrm{CC} \leq 0.40$ in some cells. This occurred because the IMERG-V05 failed to detect some rainfall events in the NE coast, as mentioned in the POD analysis. Melo et al. (2015) also observed poor agreement along the NE coastal region evaluating the daily rainfall data of TMPA products using 
14-years time series. Similarly, Rozante et al. (2018) also detected large daily underestimation in most cells considered for the Brazilian coastal region by analysing IMERG and TMPA products. On the other hand, the worst agreement between the daily IMERG-V05 product and the gridded observed rainfall data was detected across the regions $\mathrm{N}$ and $\mathrm{CW}$, with a large number of cells presenting $\mathrm{CC}$ values ranging from less than 0.1 to 0.6 .

The spatial distribution of the IMERG-V05 product errors over Brazil shows that the ME values range between $-5.5(-75 \%)$ and $4.5(110 \%) \mathrm{mm}$ at daily temporal resolution analysis (Fig. 2e). The largest absolute underestimation and overestimation of the satellite data were observed in the region $\mathrm{N}$ for both ME and RMSE error metrics. This fact was expected because the North region, where the Amazon forest is located, is characterised by the largest amount of rainfall throughout the year. However, the range of relative ME and RMSE for region NE (from -75 to $110 \%$ and from 130 to $750 \%$, respectively) is larger than the North region (from -60 to $90 \%$ and from 100 to $400 \%$, respectively) (see Fig. S2). This effect can be observed along the coastal zone of the Brazilian NE, where considerable underestimation of the ME (higher than $\sim 1 \mathrm{~mm}$ ) was also detected, following the similar characteristics of the POD and CSI which presented low detection in the cells of the area.

\section{INSERT FIG. 2}

Fig. 2 Spatial distributions of daily (a) FAR, (b) POD, (c) CSI, (d) CC, (e) ME, and (f) RMSE.

Fig. 3 shows the box plots of metrics for the daily comparison for all of Brazil, where each point represents one analysed cell. The box delimits the first (25\%) and third (75\%) quantiles, while the strip and cross inside symbolise the median and mean, respectively. The whiskers indicate the 10 and $90 \%$ percentiles, with the circles after that representing the outliers. Overall, the three metrics related to detection of observed rainfall events show symmetric results close to each mean (Fig. 3a, b, and c). More than $90 \%$ of the cells presented values higher than 0.60 for POD and less than 0.22 for FAR, which indicates the good skill of the IMERG-V05 product in detecting daily rainfall over most of Brazil. The CC shows that most values are concentrated from 0.5 to 0.8 , demonstrating a moderate agreement between observed and estimated rainfall grid values (Fig. 3d). Only $10 \%$ of the cells exhibited a CC lower than 0.4 for the daily analysis. The ME also showed strong symmetry at daily temporal resolution, with the mean close to $0 \mathrm{~mm}$ (Fig. 3e). This low ME 
value may have been influenced by compensating positive and negative differences, as also observed by Tang et al. (2016a) in China. The RMSE was relatively high when compared to ME because there is no plus/minus compensation, with a mean value up to $7 \mathrm{~mm}$ for the evaluation of the IMERG-V05 product at grid scale. The relative mean of the daily ME and RMSE represent 5 and 200\%, respectively (see Fig. S2). This indicates a small net bias, but potentially large uncertainty.

\section{INSERT FIG. 3}

Fig. 3 Box plots of metrics over observed and estimated rainfall grids at daily temporal resolution: (a) FAR, (b) POD, (c) CSI, (d) CC, (e) ME, and (f) RMSE. The histograms show the distribution of cells for each metric.

The monthly distribution of the metrics shows a noticeable improvement of the IMERG-V05 product when compared with the daily analysis (Fig. 4). This behaviour confirms longer time averages are more representative, as also seen by Caracciolo et al. (2018), Mayor et al. (2017), Tan et al. (2017), Tang et al. (2016a), among others. Overall, the CC presented values higher than 0.80 for $90 \%$ of the cells available for the Brazilian territory in the monthly analysis, most of them concentrated close to the mean $(\mathrm{CC}=0.92)$ (Fig. 4a). As at the daily scale, the monthly results indicate a poor agreement between rain gauges and satellite rainfall grids observed over the $\mathrm{N}$ region and along the Atlantic coastal zone in NE, with $\mathrm{CC}$ reaching 0.3 in many cells. For the NE coastal zone, an underestimation of the satellite data was observed. Such underestimation was most likely caused by the prevalence of warm-rain process-dominated systems forced by the topography, which are not well-detected by the passive microwave sensors over land, as noted by Rozante et al. (2018) and analysed by Palharini and Vila (2017). Also, the calibration that works for infrared estimates in other places fails in NE Brazil and is more prone to missing heavy events due to the weakness of cloud top-rain relationship, even if it were calibrated correctly in an average sense. These factors presumably also drive the daily results reported above.

As for the daily analysis, the monthly distribution of ME exhibited symmetric values concentrated close to the mean ( $\sim 2 \mathrm{~mm}$ ), with $50 \%$ of the sample ranging from -8 to $+16 \mathrm{~mm}$ (Fig. $4 \mathrm{~b})$. Once again, the low average found for ME indicates cancellation between negative and positive values. The spatial distribution of monthly ME shows that the extreme values larger than $+60 \mathrm{~mm}$ and lower than $-60 \mathrm{~mm}$ are more concentrated 
in region $\mathrm{N}$, which is echoed in the spatial distribution of RMSE. The mean relative ME and RMSE for monthly values are 5 and $36 \%$, respectively (see Fig. S3).

\section{INSERT FIG. 4}

Fig. 4 Spatial distributions of monthly (a) CC, (c) ME, and (e) RMSE. Box plots and histograms of monthly (b) CC, (d) ME, and (e) RMSE.

\section{Overall, the comparison between the annual rainfall grids shows that the IMERG-V05 product is fairly} effective at representing the pattern of rainfall over Brazil (see Fig. 1c and d). However, some discrepancies between the spatial distribution of rainfall are observed, mainly in region N. The disagreements detected in region $\mathrm{N}$ both underestimate and overestimate the distributed rain gauge data. This behaviour suggests a problem due to the sparsity of observed data available to interpolate across region $\mathrm{N}$. The cumulative frequency distribution of the observed gridded data demonstrates that $5 \%$ of the cells which represent annual rainfall higher than 3,000 $\mathrm{mm}$ show non-normal distributions, strengthening the case that the discrepancies are concentrated in region N (Fig. 5). Similar behaviour was also observed by Tang et al. (2016a) over the Tibetan Plateau, where the sparse gauge network used for the interpolation probably reduced the reliability of metrics calculated against such ground reference. Additionally, we observe that the IMERG-V05 product underestimated the annual rainfall along the NE coastal region. This performance follows the general pattern observed in the daily and monthly analyses when the IMERG-V05 product was not successful in detecting the rainfall events across this area. Additional analyses are necessary in order to assess the possible causes of different performances over Brazil.

\section{INSERT FIG. 5}

Fig. 5 Quantile-quantile (Q-Q) plot comparing the cumulative distribution of the IMERG-V05 Final product and ground-based gridded rainfall data. The solid lines represent theoretical normal distributions.

\subsection{National-scale evaluation}

This evaluation analysed the national comparison between the series from IMERG-V05 and rain gauge grids using the areal means for the entire country. The analysis reveals a strong agreement for the Brazilian territory as a whole, with the satellite data matching the average rainfall records at daily and monthly time scales 
(Fig. 6). Generally, the regression line in the scatter plots demonstrates a slight overestimation by the IMERGV05 product at daily and monthly time scales. Analogous performance analysing the mean areal precipitation was also noticed in others national-scale studies (e.g. Caracciolo et al., 2018; Mayor et al., 2017; Tan and Duan, 2017; Tang et al., 2016a). The national CC at daily and monthly temporal resolutions were 0.96 and 0.99 , respectively. These values of the agreement are higher than those from the analysis of the daily and monthly average of individual cells ( 0.68 and 0.96 , respectively). This shows that the areal aggregation leads to an improvement of the satellite product, indicating a good efficacy of the IMERG-V05 product to estimate precipitation over large areas.

\section{INSERT FIG. 6}

Fig. 6 Scatter plots and metrics of rainfall comparisons for national-scale evaluation over Brazil at (a) daily and (b) monthly timescales.

Comparisons between ground-based and IMERG-V05 data at national scale show the low variability of ME and RMSE at daily ( 0.09 and $0.78 \mathrm{~mm}$, respectively) and monthly (2.7 and $6.4 \mathrm{~mm}$, respectively) time scales. The annual average rainfall at national-scale estimated by the IMERG-V05 product for 2016 was 1,647 $\mathrm{mm}$, while the average rainfall of the interpolated data for the same year was $1,615 \mathrm{~mm}$.

\subsection{Subarea evaluation}

Fig. 7 shows the scatter plots and evaluation metrics based on the mean areal rainfall for the five selected subareas. Each subarea was individually analysed in order to expose the problem related to the low density of gauges used for the interpolation in some regions. Also, this analysis provides more detail on the error characteristics of the IMERG-V05 product. Thus, subareas with a relatively high density of ground-based points were carefully chosen. At the daily time scale, the analysis indicates that the IMERG-V05 product presented a very good agreement for all subareas, with CC ranging between $0.80(\mathrm{~N})$ and 0.92 (NE). Similarly, the high values of POD (from 0.71 to 0.89 ) and CSI (from 0.65 to 0.88 ) showed satisfactory performance of the IMERG-V05 product in detecting the ground-based rainfall events in the subareas. The FAR presented values close to zero for almost all subareas, indicating low false alarms when regions with high density of in-situ data are considered for the analyses. The exception was noticed in region NE $(F A R=0.23)$ because that subarea is 
placed in a dry zone, where there are fewer events to be correctly detected. Muhammad et al. (2018) also found noted low performance of satellite rainfall detection in the driest regions of Pakistan. In addition, more localised rainfall events in semiarid regions can be missed either by rain gauges or reduced to a very low quantity from averaging up to the satellite grid. Conversely, the subarea located in the region NE presented absolute values of ME and RMSE closer to zero due to the low rainfall depth throughout the year, but representing the highest relative values at daily (32.3 and 196\%, respectively) and monthly (32.2 and 47.4\%, respectively) temporal scales (see Table S1). Once again, the subarea located in region $\mathrm{N}$ exhibited the highest absolute values of ME and RMSE because of the largest number of days with rain and the high annual rainfall depth. Nevertheless, the relative ME and RMSE present similar values when compared to regions S, SE, and CW (see Table S1). Overall, all subareas presented a significant improvement of the metrics at the monthly time scale, with most metrics showing near perfect indices by comparing the areal mean of the interpolated gauge data and the IMERG-V05 product.

\section{INSERT FIG. 7}

Fig. 7 Metrics for the subarea analysis at daily (a, c, e, g, and i) and monthly (b, d, f, h, and j) scales based on the mean areal precipitation in the five official geographical regions in Brazil.

\subsection{Categorical analysis}

A categorical analysis was conducted to determine the direct influence of several factors on the daily agreement between the ground-based gridded rainfall data and the IMERG-V05 product. Fig. 8 shows the CC against the density of gauges (left column) and altitude (right column) categorised by the five regions in Brazil. Because of a large number of cells, the concentration of points was coloured in a normalised scale from zero (red) to one (blue), representing the highest and lowest concentrations, respectively. Overall, we observe that the $\mathrm{CC}$ inversely correlates to the density of gauges in regions $\mathrm{N}$ and $\mathrm{CW}$ of the country, with values ranging from 0.1 to 0.8 in areas with less than 10 gauges per $10,000 \mathrm{~km}^{2}$. In contrast, the correlations between CC and density of gauges have a tendency to increase from this threshold, with values ranging from 0.6 to 0.8 . Meanwhile, regions S and SE presented similar behaviour, with CC mostly higher than 0.6 and reaching 0.9 in some places. However, it is worth highlighting that both regions S and SE present the highest density of gauges used for the interpolation, mostly higher than 10 per $10,000 \mathrm{~km}^{2}$. These results reinforce the result in Tang et 
404

405

406

407

408

409

410 al. (2018) that the spatiotemporal errors computed by comparing satellite and observed rainfall data increase with the reduction of the gauge density in a grid box approach.

\section{INSERT FIG. 8}

Fig. 8 Scatter plots of CC vs gauge density (left column) and altitude (right column) categorised by the five regions in Brazil, where the number of grid boxes at each point on the plot is normalised by the highest number on the plot, and then coloured according to the color bar at the bottom of the figure.

The relation between CC and altitude shows a higher scattering and lower concentration of points with the increasing of elevation. In general, the cells located at altitudes higher than $1,000 \mathrm{~m}$ above sea level present considerable improvement of $\mathrm{CC}$, which is more noticeable in regions $\mathrm{NE}, \mathrm{CW}$, and $\mathrm{SE}$. This find differs from the study carried out by Anjum et al. (2018) in Pakistan. However, it is similar to the results found by Mayor et al. (2017) in a Mexican region, where IMERG performed better at higher altitudes. It is also noticeable that the correlations between $\mathrm{CC}$ and altitude in both regions $\mathrm{S}$ and $\mathrm{SE}$ showed analogous behaviour to those observed for the station density analysis, with small ranges of $\mathrm{CC}$ variation according to the elevation. Unlike these two regions, larger dispersions are observed in regions $\mathrm{N}, \mathrm{NE}$, and $\mathrm{CW}$ for a wide range of elevations. Therefore, the similar behaviour of the scatter plots for both categorical analyses may suggest that the density of gauges affects the altitude evaluation.

In general, the correlation showed that the IMERG-V05 performed better in regions under Subtropical (Zone C) and Semiarid (Zone B) climates (Fig. 9). The Subtropical climate is found mostly in the regions $\mathrm{S}$ and SE; whereas the Semiarid climate prevails in NE Brazil. Three climates (Cwc, Csa, and Csb) were excluded from the analysis because they cover less than $0.01 \%$ of the Brazilian territory (Alvares et al., 2013). Overall, the climates identified as being part of climatic Zone A (Tropical climate) exhibited the largest dispersions, as well as the lowest means and medians of CC values. Zone A represents the largest climate area in Brazil and covers predominantly regions $\mathrm{N}$ and $\mathrm{CW}$. Consequently, the categorical analysis by climate may have been once again influenced by the low density of rain gauges, which probably results in a poor performance of the IMERG-V05 estimates.

\section{INSERT FIG. 9}

Fig. 9 Box plots of CC categorised by climate. 


\section{Conclusions}

This study evaluated the IMERG-V05 Final Run product over Brazil using ground-based gridded rainfall data composed of 4,911 gauges as a reference. All analyses were performed in a distributed fashion at daily, monthly, and annual timescales for 2016. Overall, the results showed that the IMERG-V05 product can effectively capture the spatial patterns of rainfall across Brazil. The main specific findings of this study using a grid box-scale approach are summarised as follows:

(1) IMERG-V05 exhibited better agreement with the observed data at monthly timescale when compared to daily timescale in all analyses. Nevertheless, the IMERG-V05 presented a slight tendency in overestimating the gridded observed data at all analysed timescales.

(2) The performance of IMERG-V05 in the grid-scale and national-scale evaluations presented some variations as a function of the analysed region. Based on these two evaluations, the rainfall estimated by the satellite product exhibited higher errors and biases in regions $\mathrm{N}$ and $\mathrm{CW}$, as well as along the Atlantic coast of region NE. The underestimation evident in the satellite product for the region NE is likely associated with topographic forcing that favours warm-rain process systems which cannot be detected very well by passive microwave sensors over land.

(3) The subarea evaluation revealed that the IMERG-V05 product compares well with the interpolated data in specific areas with high density of rain gauges, including region N. The categorical analysis confirmed that the low density of rain gauges in regions $\mathrm{N}$ and $\mathrm{CW}$ can be a source of large deviations, errors, and biases in the evaluation of the satellite rainfall product.

Based on the findings of this study, the IMERG-V05 Final Run product can be used as a source of rainfall data to complement the ground precipitation measurements in most parts of the Brazilian territory. The exception is in the coastal region of the Brazilian NE, where the IMERG-V05 product needs a bias correction procedure due to the large underestimation probably caused by the inability of the microwave and infrared sensors in to properly detect rain-warm events. Moreover, the IMERG-V05 estimates for regions N and CW need to be carefully used because of some uncertainties in the data which are probably associated with the low density of rain gauges used to create the ground-based gridded product.

Finally, this study highlights that the relatively high spatiotemporal resolution of the IMERG-V05 product can favour its application for many purposes in Brazil such as hydrological modelling. However, further 
460

461

462

463

464

465

466

467

468

469

470

471

472

473

474

475

476

477

478

479

480

481

482

483

484

485

486

487

488

489

490

improvements of the IMERG-V05 product are needed for providing more accurate rainfall estimates mainly along the coastal zone of NE Brazil. Furthermore, studies exploring the characteristics of hourly and half-hourly estimates of the IMERG-V05 product over Brazil are strongly recommended.

Acknowledgements: The authors would like to acknowledge the financial support from FINEP (Brazilian Innovation Agency) granted to the BRAMAR (BRAzil Managed Aquifer Recharge, grant no. 557/2013) project. The Brazilian authors are grateful to the Brazilian National Council for Scientific and Technological Development (CNPq), Coordination for the Improvement of Higher Education and Personal (CAPES), Paraíba Research Foundation (FAPESQ-PB), and São Paulo Research Foundation (FAPESP, process 2016/23546-7) for the financial support. The NASA authors (GHJ and WAP) were funded under the Precipitation Measurement Missions and Global Precipitation Measurement (GPM) mission projects. Special thanks are given to ANA (Brazilian National Water Agency), INMET (the Brazilian National Institute of Meteorology), and the sixteen Brazilian regional water agencies (specially ADASA, CAESB, DAEE, FUNCEME, and AGUASPARANÁ) for providing the ground-based rainfall data.

\section{References}

Alvares, C.A., Stape, J.L., Sentelhas, P.C., De Moraes Gonçalves, J.L., Sparovek, G., 2013. Köppen’s climate classification map for Brazil. Meteorol. Zeitschrift 22, 711-728. doi:10.1127/0941-2948/2013/0507

Anjum, M.N., Ding, Y., Shangguan, D., Ahmad, I., Ijaz, M.W., Farid, H.U., Yagoub, Y.E., Zaman, M., Adnan, M., 2018. Performance evaluation of latest integrated multi-satellite retrievals for Global Precipitation Measurement (IMERG) over the northern highlands of Pakistan. Atmos. Res. 205, 134-146. doi:10.1016/j.atmosres.2018.02.010

Asong, Z.E., Razavi, S., Wheater, H.S., Wong, J.S., 2017. Evaluation of Integrated Multisatellite Retrievals for GPM (IMERG) over Southern Canada against Ground Precipitation Observations: A Preliminary Assessment. J. Hydrometeorol. 18, 1033-1050. doi:10.1175/JHM-D-16-0187.1

Baik, J., Choi, M., 2015. Spatio-temporal variability of remotely sensed precipitation data from COMS and TRMM: Case study of Korean peninsula in East Asia. Adv. Sp. Res. 56, 1125-1138. doi:10.1016/j.asr.2015.06.015

Beria, H., Nanda, T., Bisht, D.S., Chatterjee, C., 2017. Does the GPM mission improve the systematic error component in satellite rainfall estimates over TRMM? An evaluation at a pan-India scale. Hydrol. Earth Syst. Sci. 21, 6117-6134. doi:10.5194/hess-21-6117-2017

Buarque, D.C., De Paiva, R.C.D., Clarke, R.T., Mendes, C.A.B., 2011. A comparison of Amazon rainfall characteristics derived from TRMM, CMORPH and the Brazilian national rain gauge network. J. Geophys. Res. Atmos. 116, 1-12. doi:10.1029/2011JD016060 
491

492

493

494

495

496

497

498

499

500

501

502

503

504

505

506

507

508

509

510

511

512

513

514

515

516

517

518

519

520

521

Caracciolo, D., Francipane, A., Francesco, V., Noto, L.V., 2018. Performances of GPM satellite precipitation over the two major Mediterranean islands CLIMB -Climate Induces Changes on the Hydrology of Mediterranean Basins View project CLIMB FP7 View project. Atmos. Res. 213, 309-322. doi:10.1016/j.atmosres.2018.06.010

Coelho, V.H.R., Montenegro, S., Almeida, C.N., Silva, B.B., Oliveira, L.M., Gusmão, A.C. V, Freitas, E.S., Montenegro, A.A.A., 2017. Alluvial groundwater recharge estimation in semi-arid environment using remotely sensed data. J. Hydrol. 548, 1-15. doi:10.1016/j.jhydrol.2017.02.054

Cohen Liechti, T., Matos, J.P., Boillat, J.L., Schleiss, A.J., 2012. Comparison and evaluation of satellite derived precipitation products for hydrological modeling of the Zambezi River Basin. Hydrol. Earth Syst. Sci. 16, 489-500. doi:10.5194/hess-16-489-2012

Collischonn, B., Collischonn, W., Tucci, C.E.M., 2008. Daily hydrological modeling in the Amazon basin using TRMM rainfall estimates. J. Hydrol. 360, 207-216. doi:10.1016/j.jhydrol.2008.07.032

Curtarelli, M.P., Rennó, C.D., Alcântara, E.H., 2014. Evaluation of the Tropical Rainfall Measuring Mission 3B43 product over an inland area in Brazil and the effects of satellite boost on rainfall estimates. J. Appl. Remote Sens. 8, 083589. doi:10.1117/1.JRS.8.083589

De Paiva, R.C.D., Buarque, D.C., Collischonn, W., Bonnet, M.P., Frappart, F., Calmant, S., Bulhões Mendes, C.A., 2013. Large-scale hydrologic and hydrodynamic modeling of the Amazon River basin. Water Resour. Res. 49, 1226-1243. doi:10.1002/wrcr.20067

Delahaye, F., Kirstetter, P.E., Dubreuil, V., Machado, L.A.T., Vila, D.A., Clark, R., 2015. A consistent gauge database for daily rainfall analysis over the Legal Brazilian Amazon. J. Hydrol. 527, 292-304. doi:10.1016/j.jhydrol.2015.04.012

Dezfuli, A.K., Ichoku, C.M., Huffman, G.J., Mohr, K.I., Selker, J.S., van de Giesen, N., Hochreutener, R., Annor, F.O., 2017. Validation of IMERG precipitation in Africa. J. Hydrometeorol. JHM-D-17-0139.1. doi:10.1175/JHM-D-170139.1

Espinoza Villar, J.C., Ronchail, J., Guyot, J.L., Cochonneau, G., Naziano, F., Lavado, W., De Oliveira, E., Pombosa, R., Vauchel, P., 2009. Spatio-temporal rainfall variability in the Amazon basin countries (Brazil, Peru, Bolivia, Colombia, and Ecuador). Int. J. Climatol. 29, 1574-1594. doi:10.1002/joc.1791

Falck, A.S., Maggioni, V., Tomasella, J., Vila, D.A., Diniz, F.L.R., 2015. Propagation of satellite precipitation uncertainties through a distributed hydrologic model: A case study in the Tocantins-Araguaia basin in Brazil. J. Hydrol. 527, 943957. doi:10.1016/j.jhydrol.2015.05.042

Fang, J., Du, J., Xu, W., Shi, P., Li, M., Ming, X., 2013. Spatial downscaling of TRMM precipitation data based on the orographical effect and meteorological conditions in a mountainous area. Adv. Water Resour. 61, 42-50. doi:10.1016/j.advwatres.2013.08.011 
Gebregiorgis, A.S., Kirstetter, P.E., Hong, Y.E., Gourley, J.J., Huffman, G.J., Petersen, W.A., Xue, X., Schwaller, M.R., 2018. To What Extent is the Day 1 GPM IMERG Satellite Precipitation Estimate Improved as Compared to TRMM TMPA-RT? J. Geophys. Res. Atmos. 123, 1694-1707. doi:10.1002/2017JD027606

Guo, R., Liu, Y., 2016. Evaluation of satellite precipitation products with rain gauge data at different scales: Implications for hydrological applications. Water (Switzerland) 8. doi:10.3390/w8070281

Hobouchian, M.P., Salio, P., García Skabar, Y., Vila, D., Garreaud, R., 2017. Assessment of satellite precipitation estimates over the slopes of the subtropical Andes. Atmos. Res. 190, 43-54. doi:10.1016/j.atmosres.2017.02.006

Hofstra, N., New, M., 2009. Spatial variability in correlation decay distance and influence on angular-distance weighting interpolation of daily precipitation over Europe. Int. J. Climatol. 29, 1872-1880. doi:10.1002/joc.1819

Hou, A.Y., Kakar, R.K., Neeck, S., Azarbarzin, A.A., Kummerow, C.D., Kojima, M., Oki, R., Nakamura, K., Iguchi, T., 2014. The global precipitation measurement mission. Bull. Am. Meteorol. Soc. 95, 701-722. doi:10.1175/BAMS-D13-00164.1

Huffman, G.J., Bolvin, D.T., Nelkin, E.J., 2017a. Integrated Multi-satellitE Retrievals for GPM (IMERG) Technical Documentation.

Huffman, G.J., Bolvin, D.T., Nelkin, E.J., Stocker, E.F., 2017b. V05 IMERG Final Run Release Notes.

Huffman, G.J., Bolvin, D.T., Nelkin, E.J., Wolff, D.B., Adler, R.F., Gu, G., Hong, Y., Bowman, K.P., Stocker, E.F., 2007. The TRMM Multisatellite Precipitation Analysis (TMPA): Quasi-Global, Multiyear, Combined-Sensor Precipitation Estimates at Fine Scales. J. Hydrometeorol. 8, 38-55. doi:10.1175/JHM560.1

Jesus, M., Rinaldo, A., Rodr, I., Jesus, D.E.L., Al, E.T., 2015. Point rainfall statistics for ecohydrological analyses derived from satellite integrated measurements. Water Resour. Res. 2974-2985. doi:10.1002/2015WR016935.Received

Kann, A., Meirold-Mautner, I., Schmid, F., Kirchengast, G., Fuchsberger, J., Meyer, V., Tüchler, L., Bica, B., 2015. Evaluation of high-resolution precipitation analyses using a dense station network. Hydrol. Earth Syst. Sci. 19, 15471559. doi:10.5194/hess-19-1547-2015

Kidd, C., Becker, A., Huffman, G.J., Muller, C.L., Joe, P., Skofronick-Jackson, G., Kirschbaum, D.B., 2017. So, how much of the Earth's surface is covered by rain gauges? Bull. Am. Meteorol. Soc. 98, 69-78. doi:10.1175/BAMS-D-1400283.1

Kidd, C., Huffman, G., 2011. Global precipitation measurement. Meteorol. Appl. 18, 334-353. doi:10.1002/met.284

Kousky, V.E., 1979. Frontal Influences on Northeast Brazil. Mon. Weather Rev. doi:10.1175/15200493(1979)107<1140:FIONB >2.0.CO;2

Lelis, L., Bosquilia, R., Duarte, S., 2018. Assessment of Precipitation Data Generated by GPM and TRMM Satellites. Rev. Bras. Meteorol. 33, 153-163. doi:http://dx.doi.org/10.1590/0102-7786331004 rbmet.org.br Artigo 
Levizzani, V., Kidd, C., Aonashi, K., Bennartz, R., Ferraro, R.R., Huffman, G.J., Roca, R., Turk, F.J., Wang, N.Y., 2018. The activities of the International Precipitation Working Group. Q. J. R. Meteorol. Soc. doi:10.1002/qj.3214

Liu, Z., Ostrenga, D., Vollmer, B., Deshong, B., MacRitchie, K., Greene, M., Kempler, S., 2017. Global precipitation measurement mission products and services at the nasa ges disc. Bull. Am. Meteorol. Soc. 98, 437-444. doi:10.1175/BAMS-D-16-0023.1

Mahmoud, M.T., Al-zahrani, M.A., Sharif, H.O., 2018. Assessment of global precipitation measurement satellite products over Saudi Arabia. J. Hydrol. 559, 1-12. doi:10.1016/j.jhydrol.2018.02.015

Mayor, Y.G., Tereshchenko, I., Fonseca-Hernández, M., Pantoja, D.A., Montes, J.M., 2017. Evaluation of error in IMERG precipitation estimates under different topographic conditions and temporal scales over Mexico. Remote Sens. 9. doi: $10.3390 /$ rs 9050503

McMillan, H., Jackson, B., Clark, M., Kavetski, D., Woods, R., 2011. Rainfall uncertainty in hydrological modelling: An evaluation of multiplicative error models. J. Hydrol. 400, 83-94. doi:10.1016/j.jhydrol.2011.01.026

Melo, D.C.D., Xavier, A.C., Bianchi, T., Oliveira, P.T.S., Scanlon, B.R., Lucas, M.C., Wendland, E., 2015. Performance evaluation of rainfall estimates by TRMM Multi-satellite Precipitation Analysis 3B42V6 and V7 over Brazil. J. Geophys. Res. Atmos. 120, 9043-9836. doi:10.1002/2014JD022963

Melo, D.D.C.D., Scanlon, B.R., Zhang, Z., Wendland, E., Yin, L., 2016. Reservoir storage and hydrologic responses to droughts in the Paraná River basin, south-eastern Brazil 4673-4688. doi:10.5194/hess-20-4673-2016

Meng, J., Li, L., Hao, Z., Wang, J., Shao, Q., 2014. Suitability of TRMM satellite rainfall in driving a distributed hydrological model in the source region of Yellow River. J. Hydrol. 509, 320-332. doi:10.1016/j.jhydrol.2013.11.049

Mitra, A.K., Kaushik, N., Singh, A.K., Parihar, S., Bhan, S.C., 2018. Evaluation of INSAT-3D Satellite derived precipitation estimates for Heavy Rainfall Events and its Validation with Gridded GPM ( IMERG ) rainfall Dataset over the Indian region Remote Sensing Applications : Society and Environment Evaluation of INSAT-3D s. Remote Sens. Appl. Soc. Environ. 9, 91-99. doi:10.1016/j.rsase.2017.12.006

Muhammad, W., Yang, H., Lei, H., Muhammad, A., Yang, D., 2018. Improving the regional applicability of satellite precipitation products by ensemble algorithm. Remote Sens. 10, 577. doi:10.3390/rs 10040577

Naumann, G., Barbosa, P., Carrao, H., Singleton, A., Vogt, J., 2012. Monitoring drought conditions and their uncertainties in Africa using TRMM data. J. Appl. Meteorol. Climatol. 51, 1867-1874. doi:10.1175/JAMC-D-12-0113.1

Nery, J.T., Carfan, A.C., 2014. Re-analysis of pluvial precipitation in southern Brazil. Atmosfera 27, $103-115$. doi:10.1016/S0187-6236(14)71104-X

New, M., Hulme, M., Jones, P., 2000. Representing twentieth-century space-time climate variability. Part II: Development of 1901-96 monthly grids of terrestrial surface climate. J. Clim. 13, 2217-2238. doi:10.1175/1520- 
0442(2000)013<2217:RTCSTC $>2.0 . C O ; 2$

O, S., Kirstetter, P.E., 2018. Evaluation of diurnal variation of GPM IMERG-derived summer precipitation over the contiguous US using MRMS data. Q. J. R. Meteorol. Soc. doi:10.1002/qj.3218

Oliveira, R., Maggioni, V., Vila, D., Morales, C., 2016. Characteristics and diurnal cycle of GPM rainfall estimates over the Central Amazon region. Remote Sens. 8. doi:10.3390/rs8070544

Oliveira, R., Maggioni, V., Vila, D., Porcacchia, L., 2018. Using satellite error modeling to improve GPM-Level 3 rainfall estimates over the central Amazon region. Remote Sens. 10. doi:10.3390/rs10020336

Palharini, R.S.A., Vila, D.A., 2017. Climatological behavior of precipitating clouds in the northeast region of Brazil. Adv. Meteorol. 17-21.

Pombo, S., de Oliveira, R.P., 2015. Evaluation of extreme precipitation estimates from TRMM in Angola. J. Hydrol. 523, 663-679. doi:10.1016/j.jhydrol.2015.02.014

Prakash, S., Mitra, A.K., Aghakouchak, A., Liu, Z., Norouzi, H., Pai, D.S., 2018. A preliminary assessment of GPM-based multi-satellite precipitation estimates over a monsoon dominated region. J. Hydrol. 556, 865-876. doi:10.1016/j.jhydrol.2016.01.029

Prakash, S., Mitra, A.K., Pai, D.S., Aghakouchak, A., 2016. Advances in Water Resources From TRMM to GPM : How well can heavy rainfall be detected from space? Adv. Water Resour. 88, 1-7. doi:10.1016/j.advwatres.2015.11.008

Rozante, J.R. and, Vila, D.A. and, Chiquetto, Júlio Barboza and Fernandes, A. de A. and, Alvim, D.S., 2018. Evaluation of TRMM/GPM Blended Daily Products over Brazil. Remote Sens. 15, 814-815. doi:https://doi.org/10.3390/rs10060882

Satgé, F., Xavier, A., Zolá, R.P., Hussain, Y., Timouk, F., Garnier, J., Bonnet, M.P., 2017. Comparative assessments of the latest GPM mission's spatially enhanced satellite rainfall products over the main bolivian watersheds. Remote Sens. 9, 1-16. doi:10.3390/rs9040369

Schneider, U., Ziese, M., Meyer-Christoffer, A., Finger, P., Rustemeier, E., Becker, A., 2016. The new portfolio of global precipitation data products of the Global Precipitation Climatology Centre suitable to assess and quantify the global water cycle and resources. Proc. Int. Assoc. Hydrol. Sci. 374, 29-34. doi:10.5194/piahs-374-29-2016

Skofronick-Jackson, G., Kirschbaum, D., Petersen, W., Huffman, G., Kidd, C., Stocker, E., Kakar, R., 2018. The Global Precipitation Measurement (GPM) mission's scientific achievements and societal contributions: reviewing four years of advanced rain and snow observations. Q. J. R. Meteorol. Soc. doi:10.1002/qj.3313

Skofronick-Jackson, G., Petersen, W.A., Berg, W., Kidd, C., Stocker, E.F., Kirschbaum, D.B., Kakar, R., Braun, S.A., Huffman, G.J., Iguchi, T., Kirstetter, P.E., Kummerow, C., Meneghini, R., Oki, R., Olson, W.S., Takayabu, Y.N., Furukawa, K., Wilheit, T., 2017. The global precipitation measurement (GPM) mission for science and Society. Bull. 
Am. Meteorol. Soc. 98, 1679-1695. doi:10.1175/BAMS-D-15-00306.1

Sungmin, O., Foelsche, U., Kirchengast, G., Fuchsberger, J., Tan, J., Petersen, W.A., 2017. Evaluation of GPM IMERG Early, Late, and Final rainfall estimates using WegenerNet gauge data in southeastern Austria. Hydrol. Earth Syst. Sci. 21, 6559-6572. doi:10.5194/hess-21-6559-2017

Tan, J., Petersen, W.A., Kirstetter, P.-E., Tian, Y., 2017. Performance of IMERG as a Function of Spatiotemporal Scale. J. Hydrometeorol. 18, 307-319. doi:10.1175/JHM-D-16-0174.1

Tan, M., Duan, Z., 2017. Assessment of GPM and TRMM Precipitation Products over Singapore. Remote Sens. 9, 720. doi: $10.3390 /$ rs 9070720

Tan, M.L., Santo, H., 2018. Comparison of GPM IMERG, TMPA 3 B42 and PERSIANN-CDR satellite precipitation products over Malaysia. Atmos. Res. 202, 63-76. doi:10.1016/j.atmosres.2017.11.006

Tang, G., Behrangi, A., Long, D., Li, C., Hong, Y., 2018. Accounting for spatiotemporal errors of gauges: A critical step to evaluate gridded precipitation products. J. Hydrol. 559, 294-306. doi:10.1016/j.jhydrol.2018.02.057

Tang, G., Ma, Y., Long, D., Zhong, L., Hong, Y., 2016a. Evaluation of GPM Day-1 IMERG and TMPA Version-7 legacy products over Mainland China at multiple spatiotemporal scales. J. Hydrol. 533, 152-167. doi:10.1016/j.jhydrol.2015.12.008

Tang, G., Zeng, Z., Long, D., Guo, X., Yong, B., Zhang, W., Hong, Y., 2016b. Statistical and Hydrological Comparisons between TRMM and GPM Level-3 Products over a Midlatitude Basin: Is Day-1 IMERG a Good Successor for TMPA 3B42V7? J. Hydrometeorol. 17, 121-137. doi:10.1175/JHM-D-15-0059.1

Terink, W., Leijnse, H., van den Eertwegh, G., Uijlenhoet, R., 2018. Spatial resolutions in areal rainfall estimation and their impact on hydrological simulations of a lowland catchment. J. Hydrol. doi:10.1016/j.jhydrol.2018.05.045

Toté, C., Patricio, D., Boogaard, H., van der Wijngaart, R., Tarnavsky, E., Funk, C., 2015. Evaluation of satellite rainfall estimates for drought and flood monitoring in Mozambique. Remote Sens. 7, 1758-1776. doi:10.3390/rs70201758

Wang, Z., Zhong, R., Lai, C., Chen, J., 2017. Evaluation of the GPM IMERG satellite-based precipitation products and the hydrological utility. Atmos. Res. 196, 151-163. doi:10.1016/j.atmosres.2017.06.020

WMO, 1994. Guide to hydrological practices: Data acquisition and processing, analysis, forecasting and other applications.

Xavier, A.C., King, C.W., Scanlon, B.R., 2016. Daily gridded meteorological variables in Brazil (1980-2013). Int. J. Climatol. 2659, 2644-2659. doi:10.1002/joc.4518

Yang, S., Nesbitt, S.W., 2014. Statistical properties of precipitation as observed by the TRMM precipitation radar. Geophys. Res. Lett. 41, 5636-5643. doi:10.1002/2014GL060683

Zad, S.N.M., Zulkafli, Z., Muharram, F.M., 2018. Satellite rainfall (TRMM 3B42-V7) performance assessment and adjustment over Pahang river basin, Malaysia. Remote Sens. 10, 1-24. doi:10.3390/rs10030388 


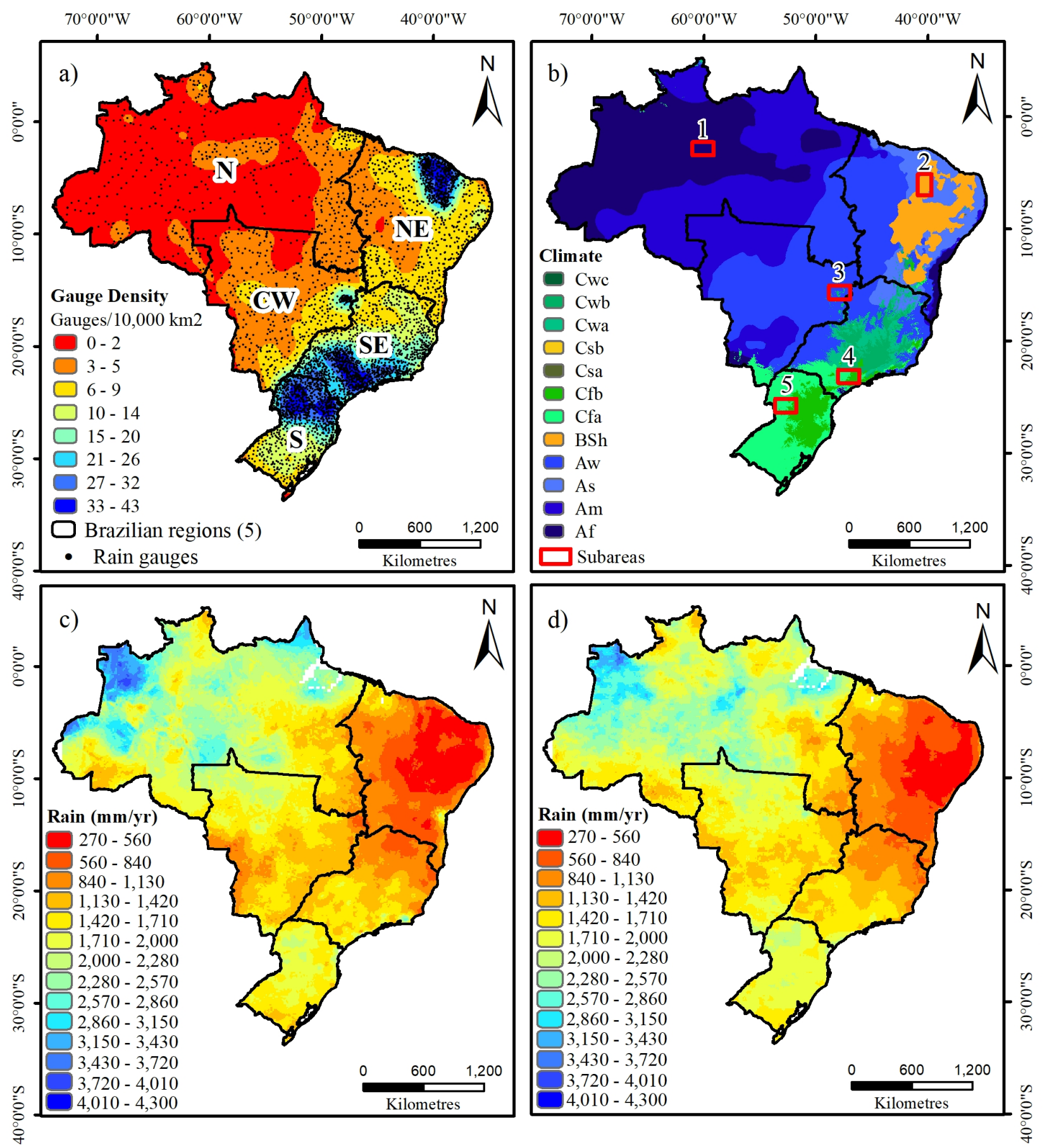




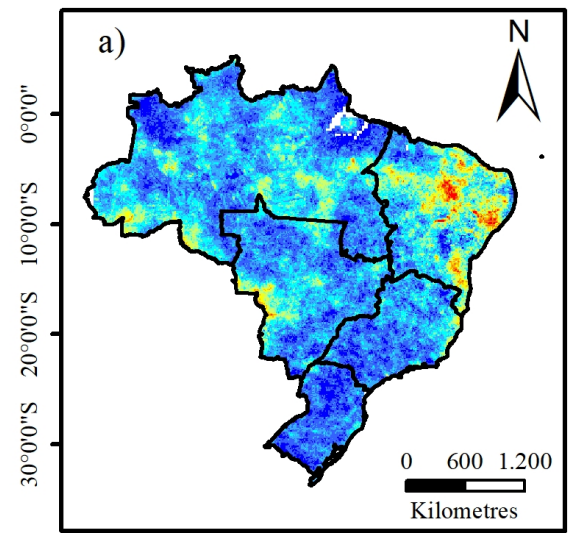

$70^{\circ} 0^{\prime} 0^{\prime \prime} \mathrm{W} \quad 60^{\circ} 0^{\prime} 0^{\prime \prime} \mathrm{W} \quad 50^{\circ} 0^{\prime} 0^{\prime \prime} \mathrm{W} \quad 40^{\circ} 0^{\prime} 0^{\prime \prime} \mathrm{W}$

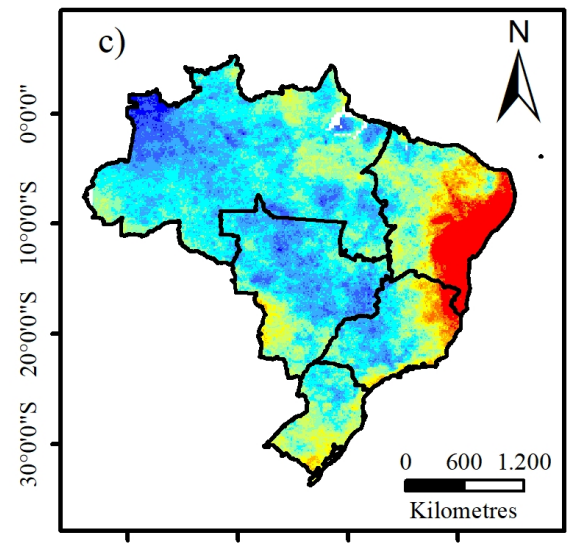

$70^{\circ} 0^{\prime} 0^{\prime \prime} \mathrm{W} \quad 60^{\circ} 0^{\prime} 0^{\prime \prime} \mathrm{W} \quad 50^{\circ} 0^{\prime} 0^{\prime \prime} \mathrm{W} \quad 40^{\circ} 0^{\prime} 0^{\prime \prime} \mathrm{W}$

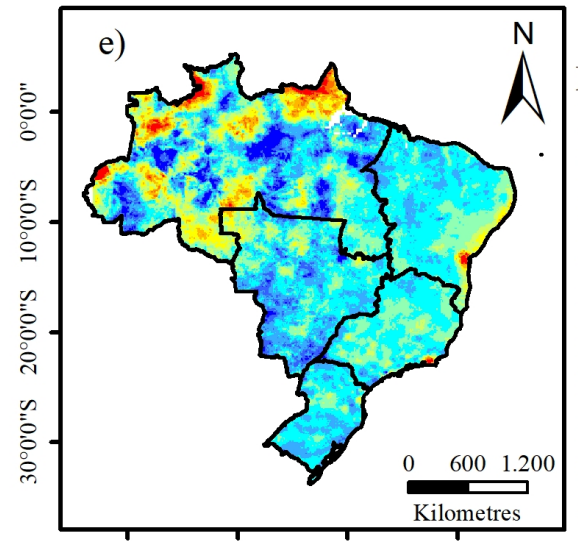

$70^{\circ} 0^{\prime} 0^{\prime \prime} \mathrm{W} \quad 60^{\circ} 0^{\prime} 0^{\prime \prime} \mathrm{W} \quad 50^{\circ} 0^{\prime} 0^{\prime \prime} \mathrm{W} \quad 40^{\circ} 0^{\prime} 0^{\prime \prime} \mathrm{W}$
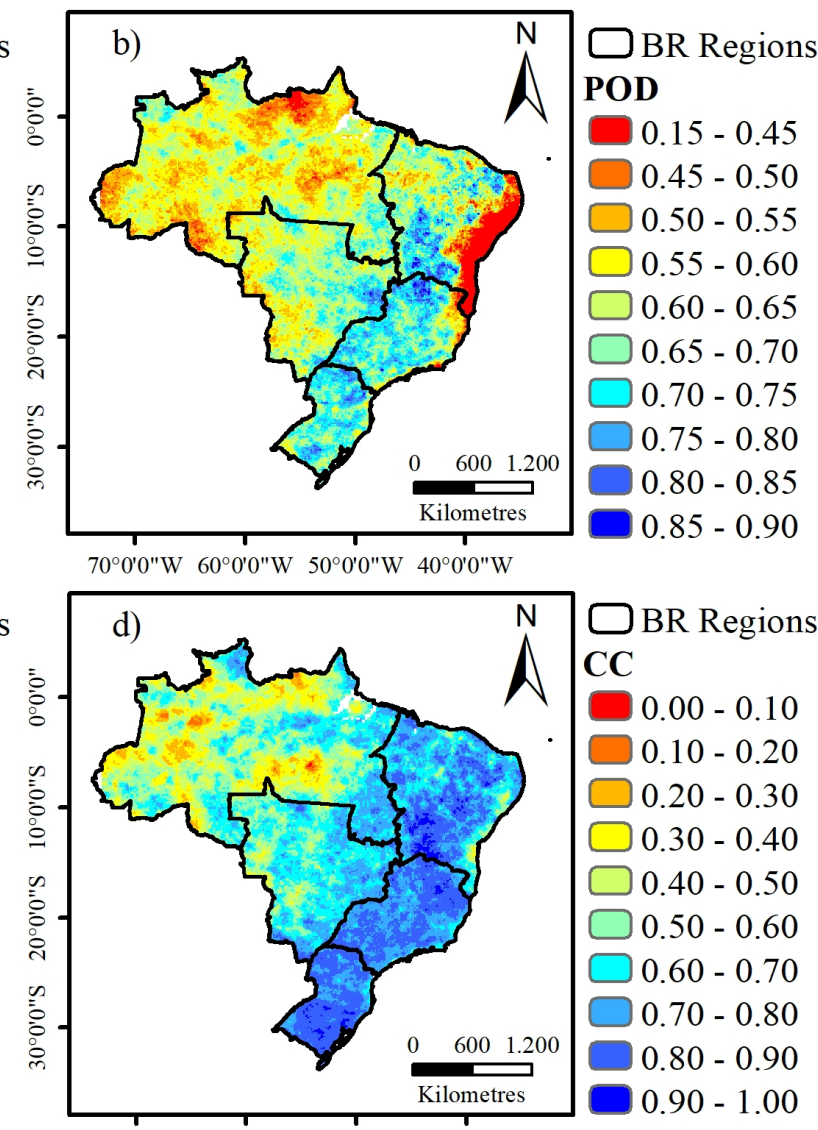

$\square$ BR Regions

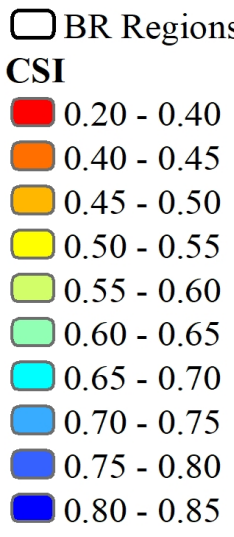

CC

$0.00-0.10$

$0.10-0.20$

$0.20-0.30$

$0.30-0.40$

$0.40-0.50$

$0.50-0.60$

$0.60-0.70$

$0.70-0.80$

$70^{\circ} 0^{\prime} 0^{\prime \prime} \mathrm{W} \quad 60^{\circ} 0^{\prime} 0^{\prime \prime} \mathrm{W} \quad 50^{\circ} 0^{\prime} 0^{\prime \prime} \mathrm{W} \quad 40^{\circ} 0^{\prime} 0^{\prime \prime} \mathrm{W}$

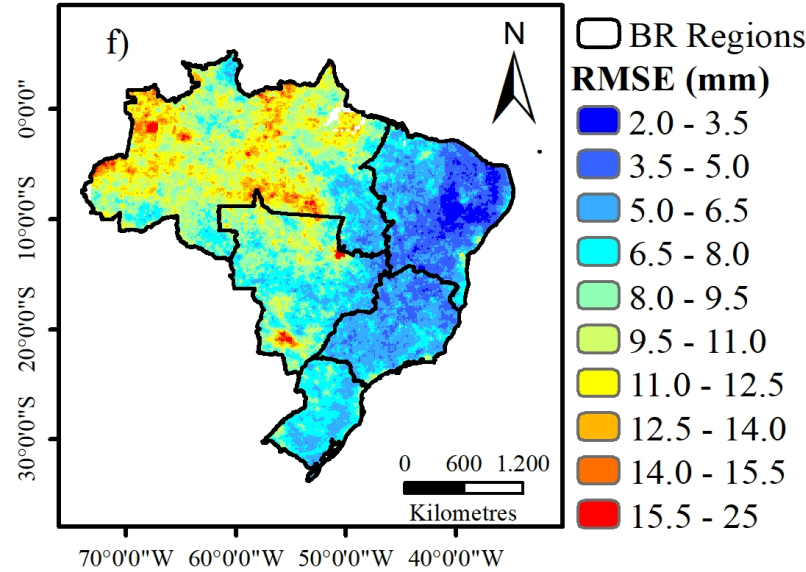



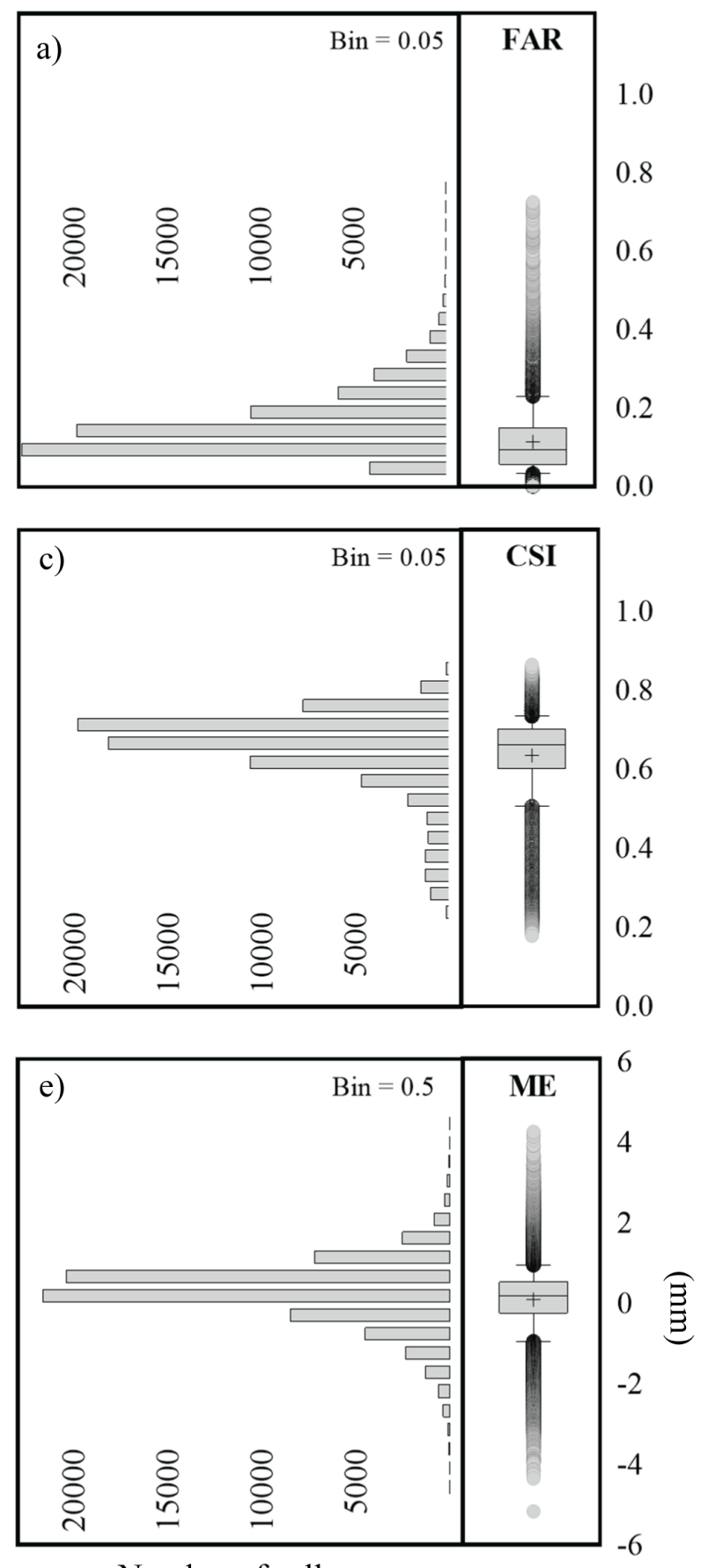

Number of cells
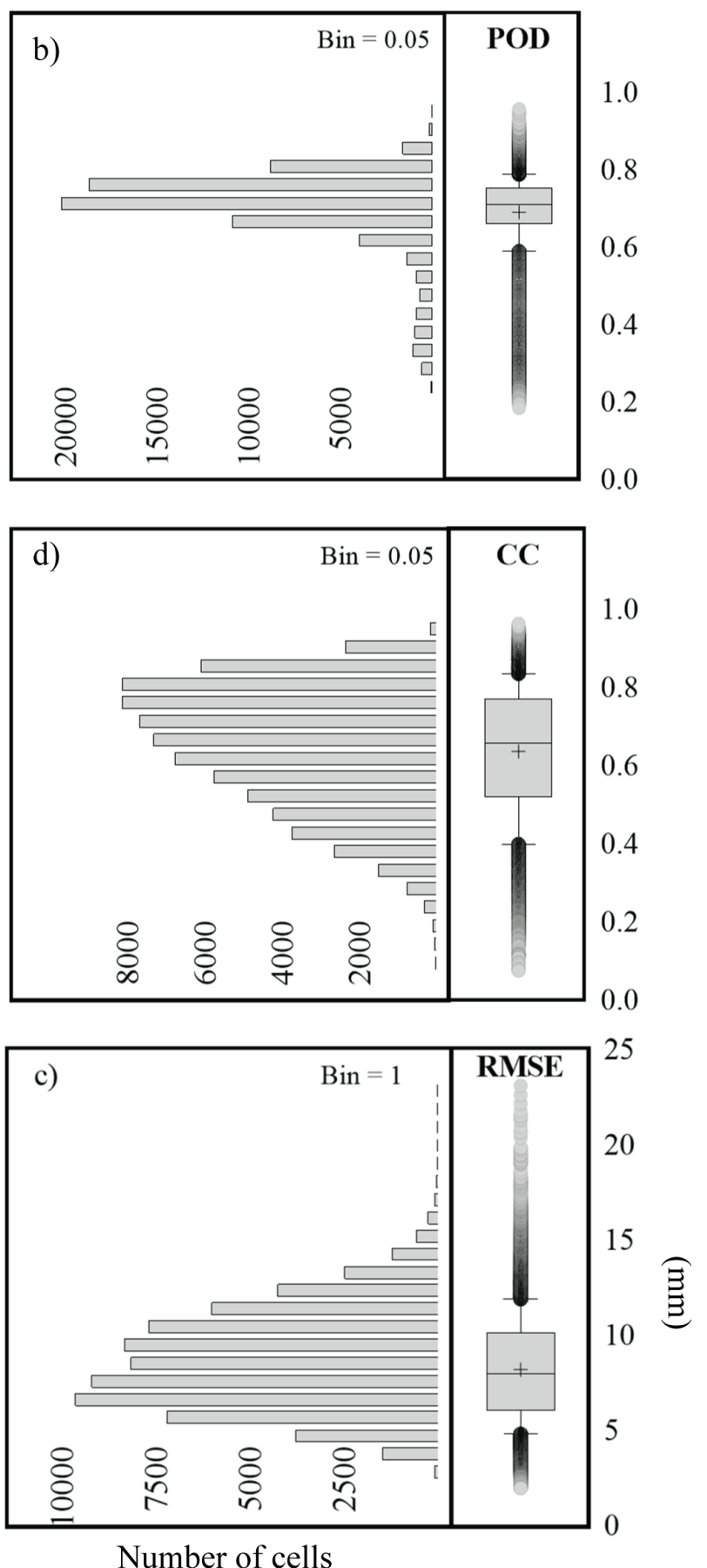


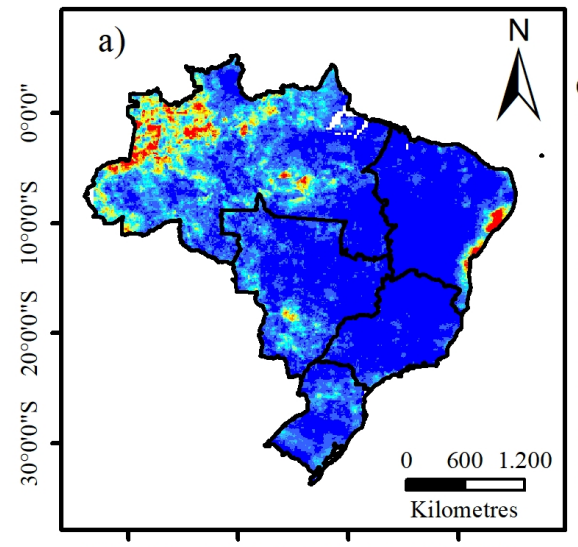

$\square$ BR Regions
CC $0.95-1.00$
$0.90-0.95$
$\square 0.85-0.90$
$\square 0.80-0.85$
$\square 0.75-0.80$
$\square 0.70-0.75$
$\square 0.65-0.70$
$\square 0.60-0.65$
$0.55-0.60$
$-0.15-0.55$

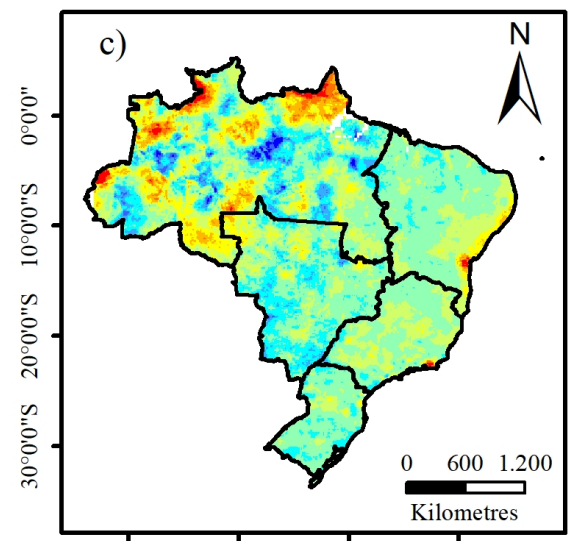

$\square$ BR Regions ME (mm)

$80-130$

$60-80$

$40-60$

$\square 20-40$

$\square 0-20$

$\square-20-0$

$\square-40--20$

$\square-60--40$

$-80--60$

$70^{\circ} 0^{\prime} 0 " \mathrm{~W} \quad 60^{\circ} 0^{\prime} 0^{\prime \prime} \mathrm{W} \quad 50^{\circ} 0^{\prime} 0^{\prime \prime} \mathrm{W} \quad 40^{\circ} 0^{\prime} 0^{\prime \prime} \mathrm{W}$

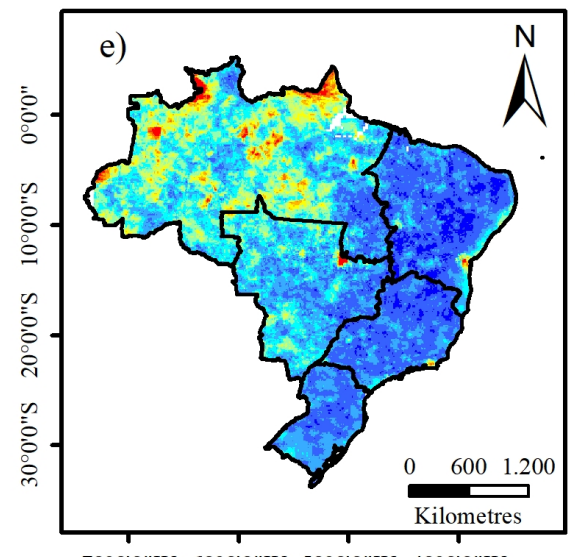

$-135--80$

$\square$ BR Regions RMSE (mm)

0 - 15

$15-30$

$30-45$

$\square 45-60$

$\square 60-75$

$\square 75-90$

$\square 90-105$

$\square 105-120$

$120-135$

$70^{\circ} 0^{\prime} 0^{\prime \prime} \mathrm{W} \quad 60^{\circ} 0^{\prime} 0^{\prime \prime} \mathrm{W} \quad 50^{\circ} 0^{\prime} 0^{\prime \prime} \mathrm{W} \quad 40^{\circ} 0^{\circ} 0^{\prime \prime} \mathrm{W}$
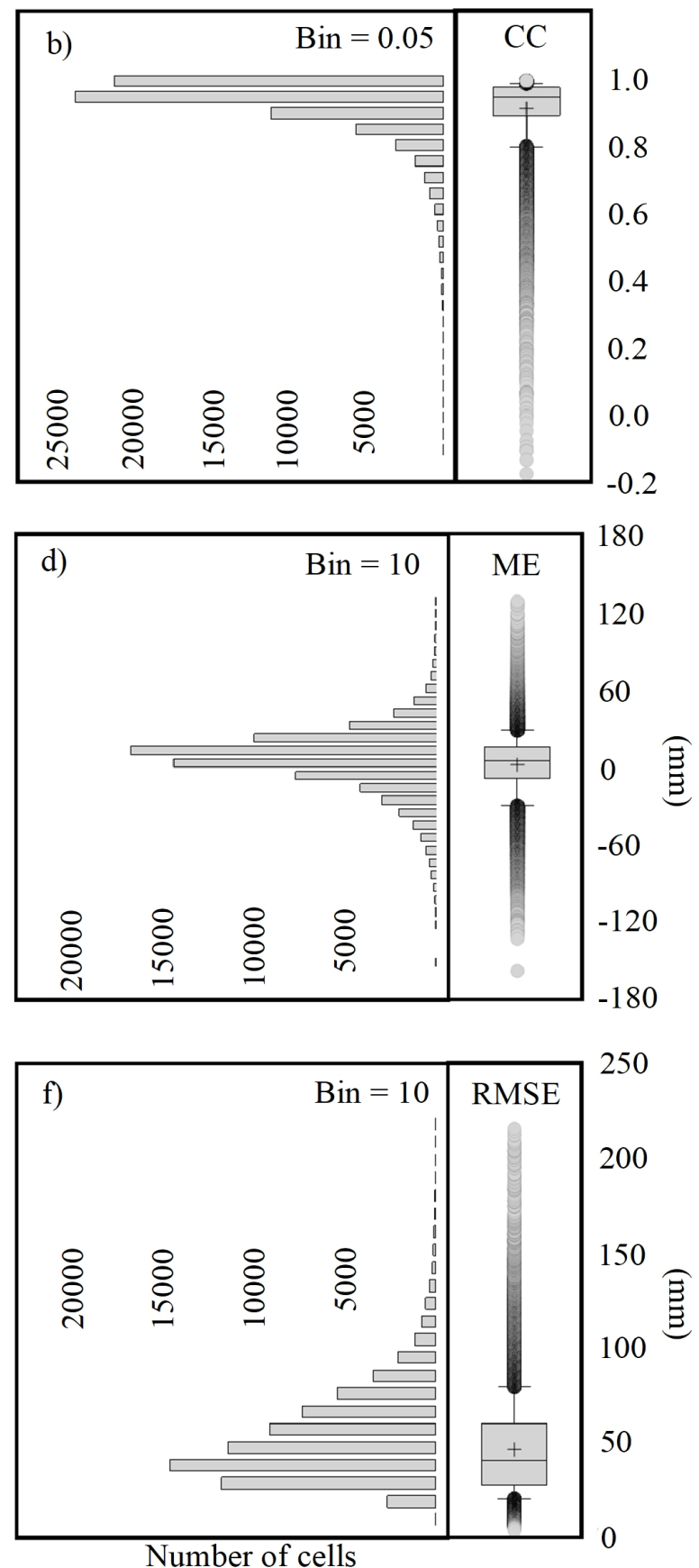


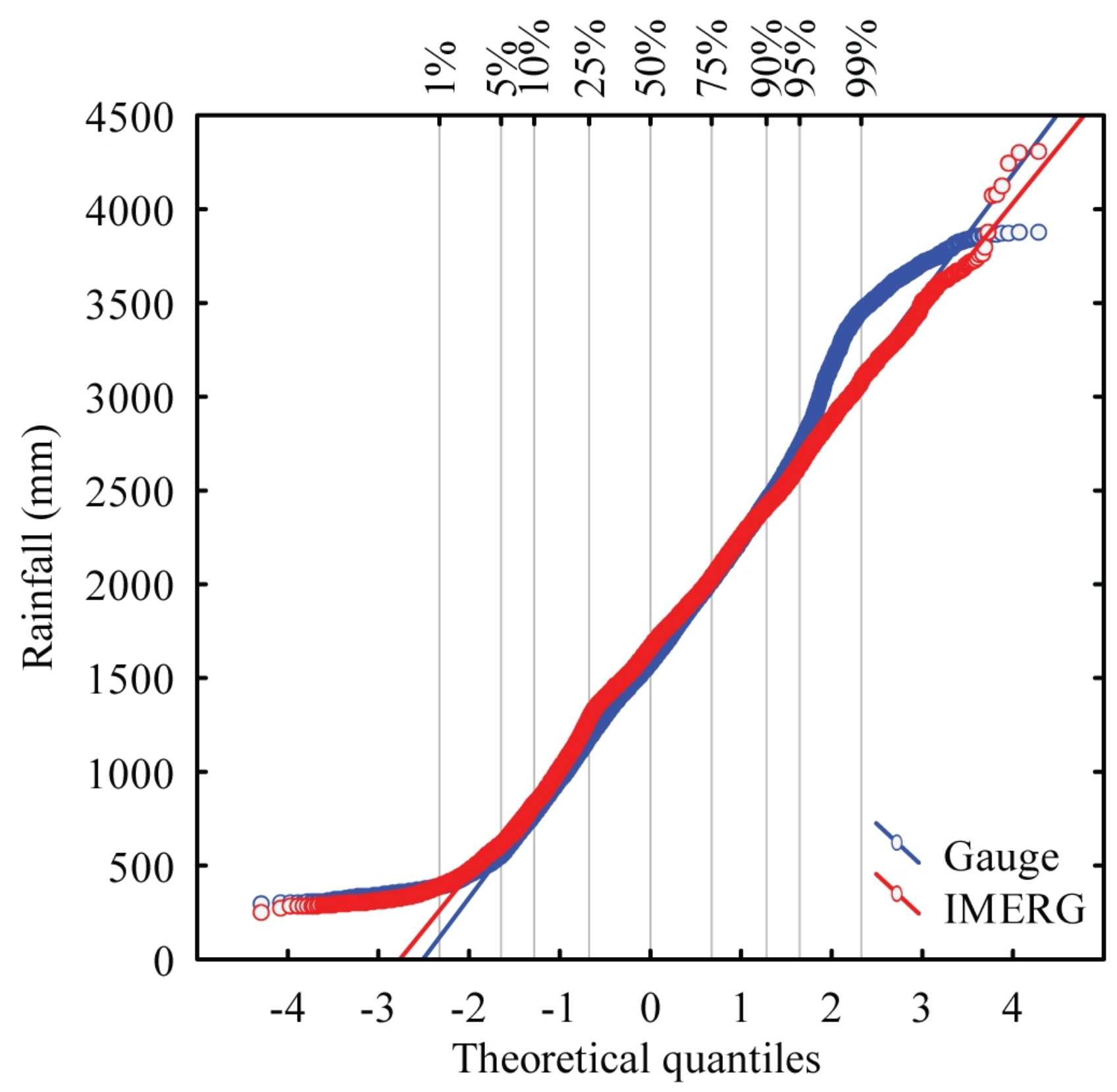



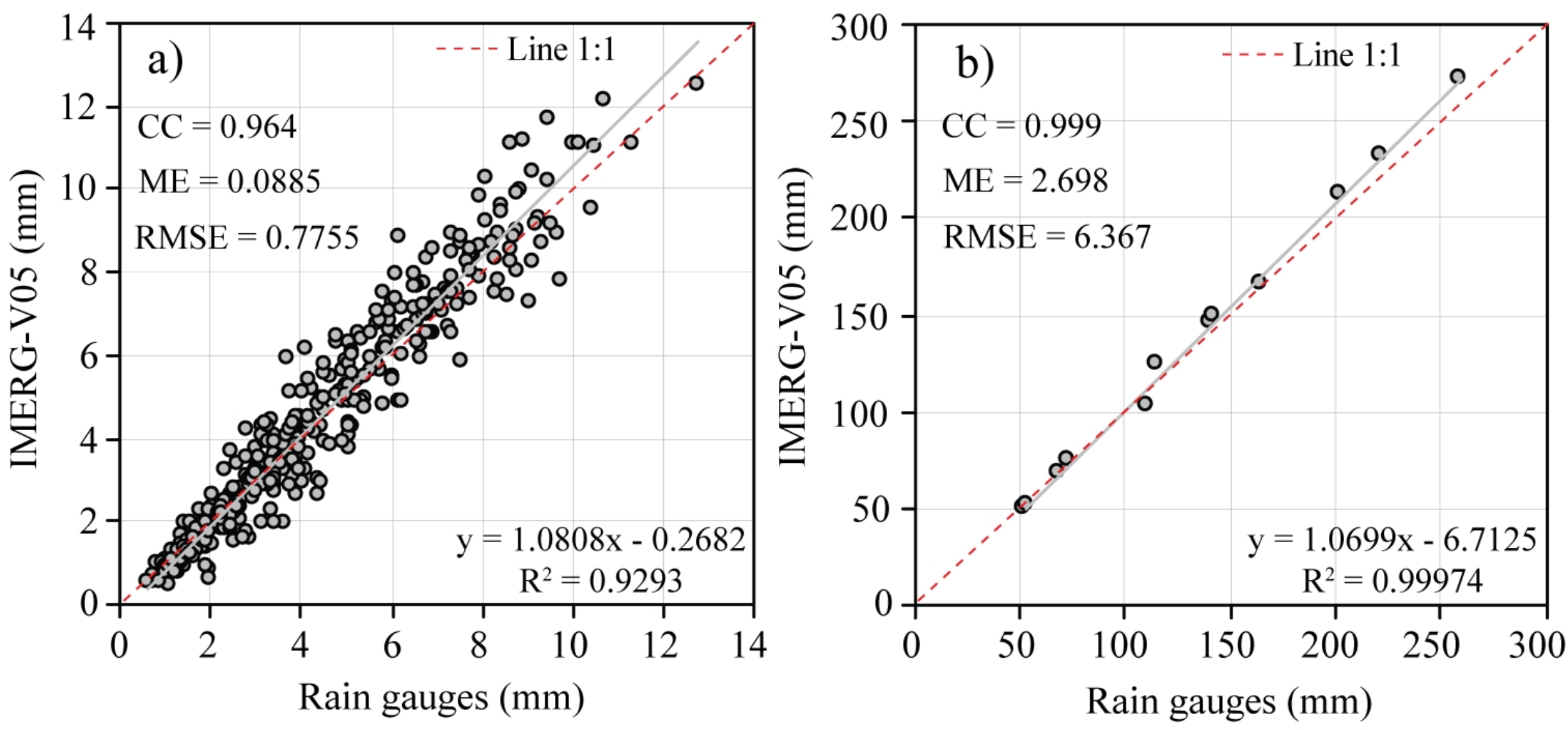


\section{Daily}
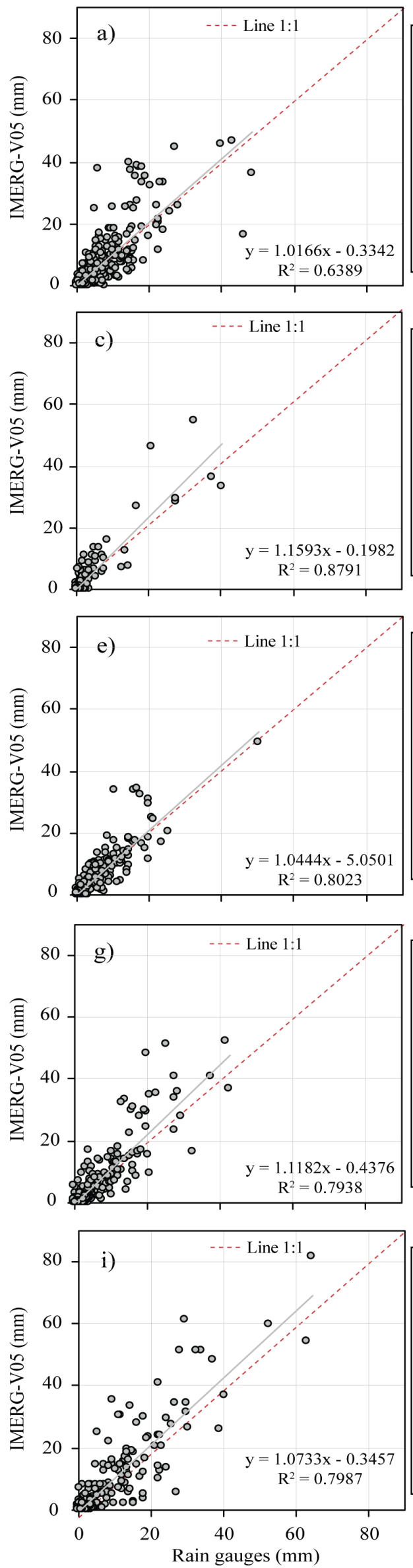

Monthly
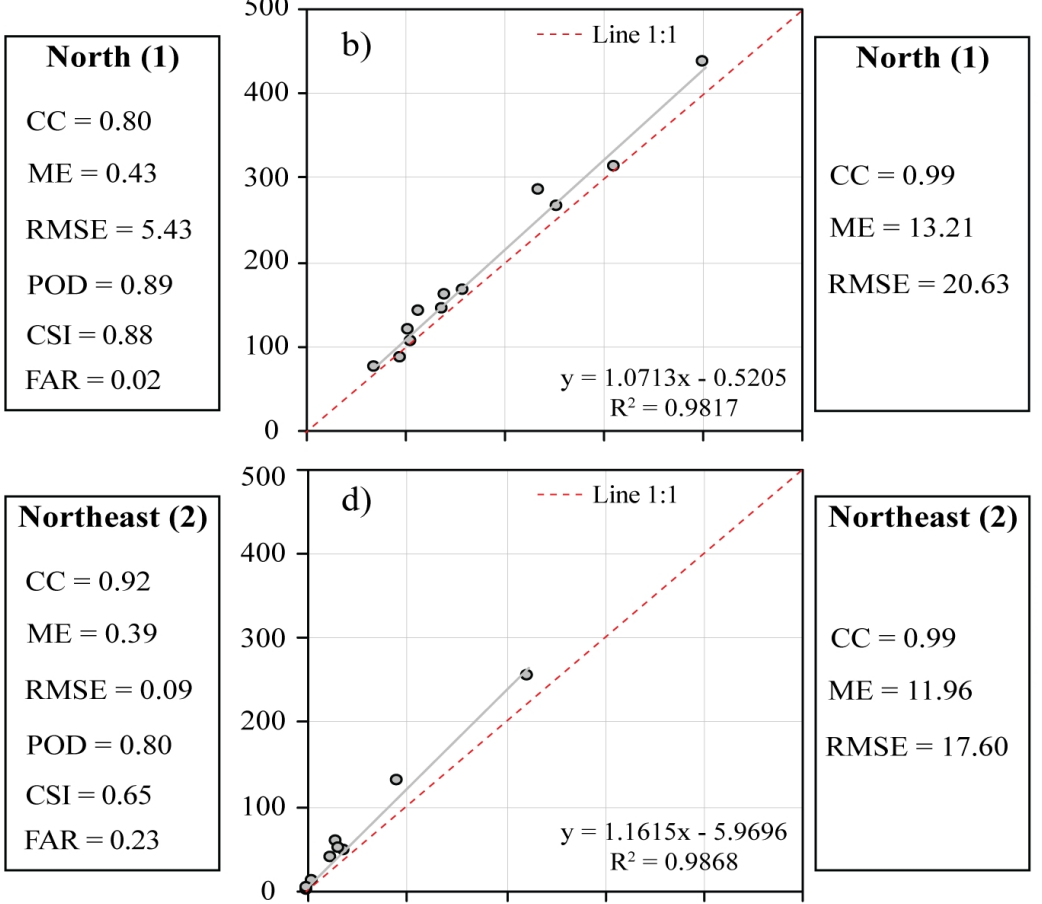

Northeast (2)

\begin{tabular}{|l|}
\hline Northeast (2) \\
$\mathrm{CC}=0.92$ \\
$\mathrm{ME}=0.39$ \\
$\mathrm{RMSE}=0.09$ \\
$\mathrm{POD}=0.80$ \\
$\mathrm{CSI}=0.65$ \\
$\mathrm{FAR}=0.23$ \\
\hline
\end{tabular}

\begin{tabular}{l} 
Central-W (3) \\
$\mathrm{CC}=0.90$ \\
$\mathrm{ME}=0.20$ \\
$\mathrm{RMSE}=2.92$ \\
$\mathrm{POD}=0.89$ \\
$\mathrm{CSI}=0.85$ \\
$\mathrm{FAR}=0.06$ \\
\hline
\end{tabular}

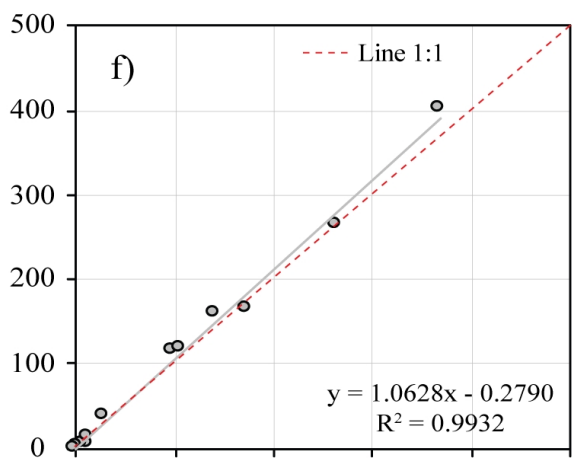

$\mathrm{CC}=0.99$

$\mathrm{ME}=11.96$

RMSE $=17.60$

Central-W (3)

$\mathrm{CC}=1.00$

$\mathrm{ME}=6.06$

RMSE $=13.67$

Southeast (4)

$\mathrm{CC}=0.89$

$\mathrm{ME}=0.06$

RMSE $=4.03$

$\mathrm{POD}=0.71$

CSI $=0.70$

FAR $=0.02$

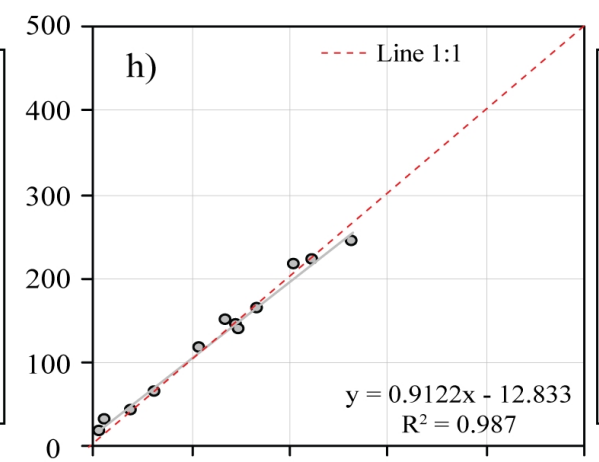

Southeast (4)

$\mathrm{CC}=0.99$

$\mathrm{ME}=1.63$

RMSE $=11.06$

\begin{tabular}{|l|}
\hline \multicolumn{1}{|c|}{ South (5) } \\
$\mathrm{CC}=0.89$ \\
$\mathrm{ME}=0.03$ \\
$\mathrm{RMSE}=5.00$ \\
$\mathrm{POD}=0.72$ \\
$\mathrm{CSI}=0.69$ \\
$\mathrm{FAR}=0.06$ \\
\hline
\end{tabular}

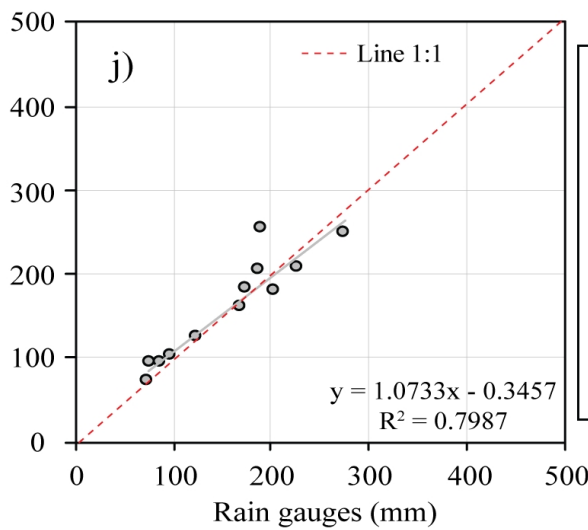



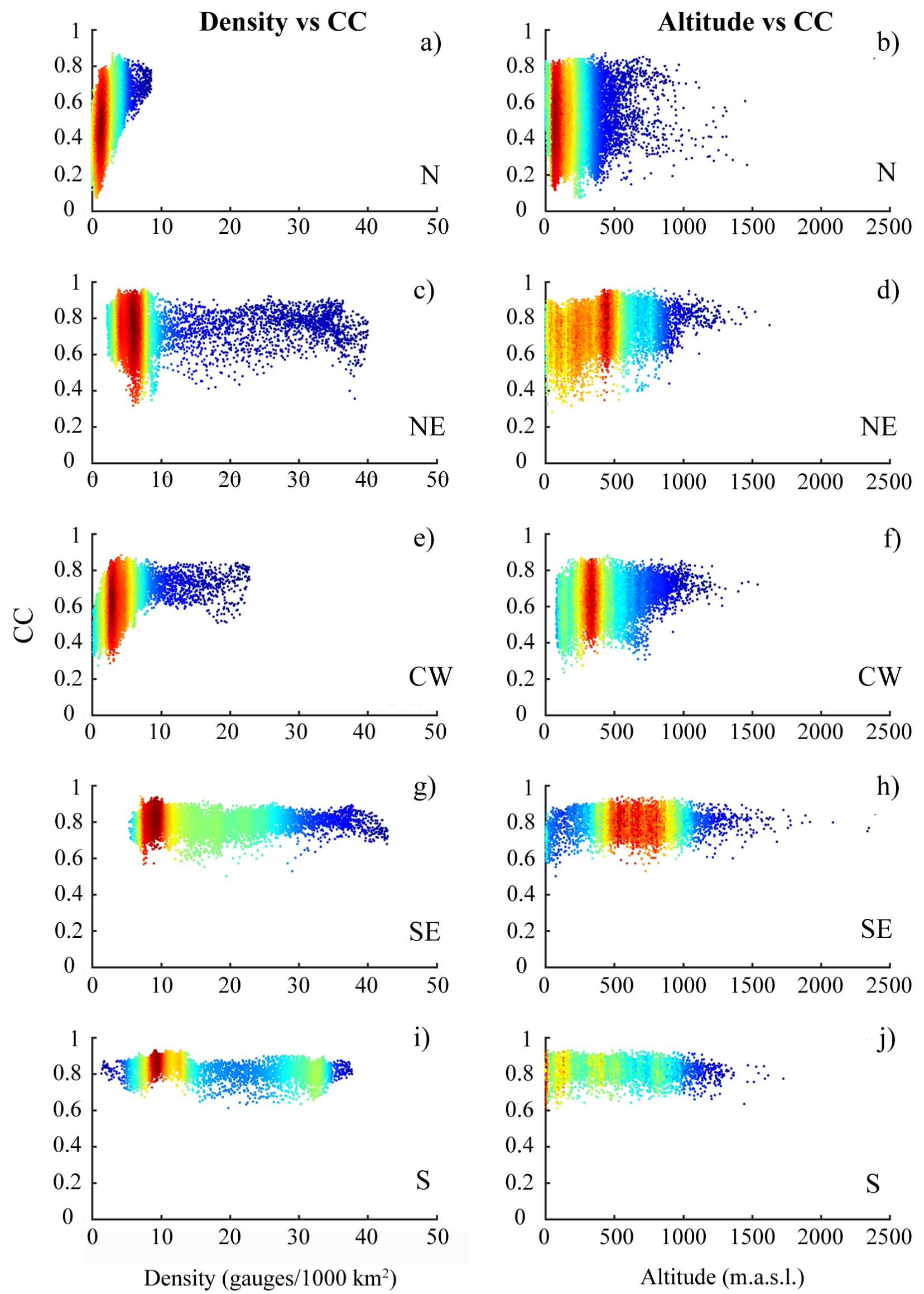


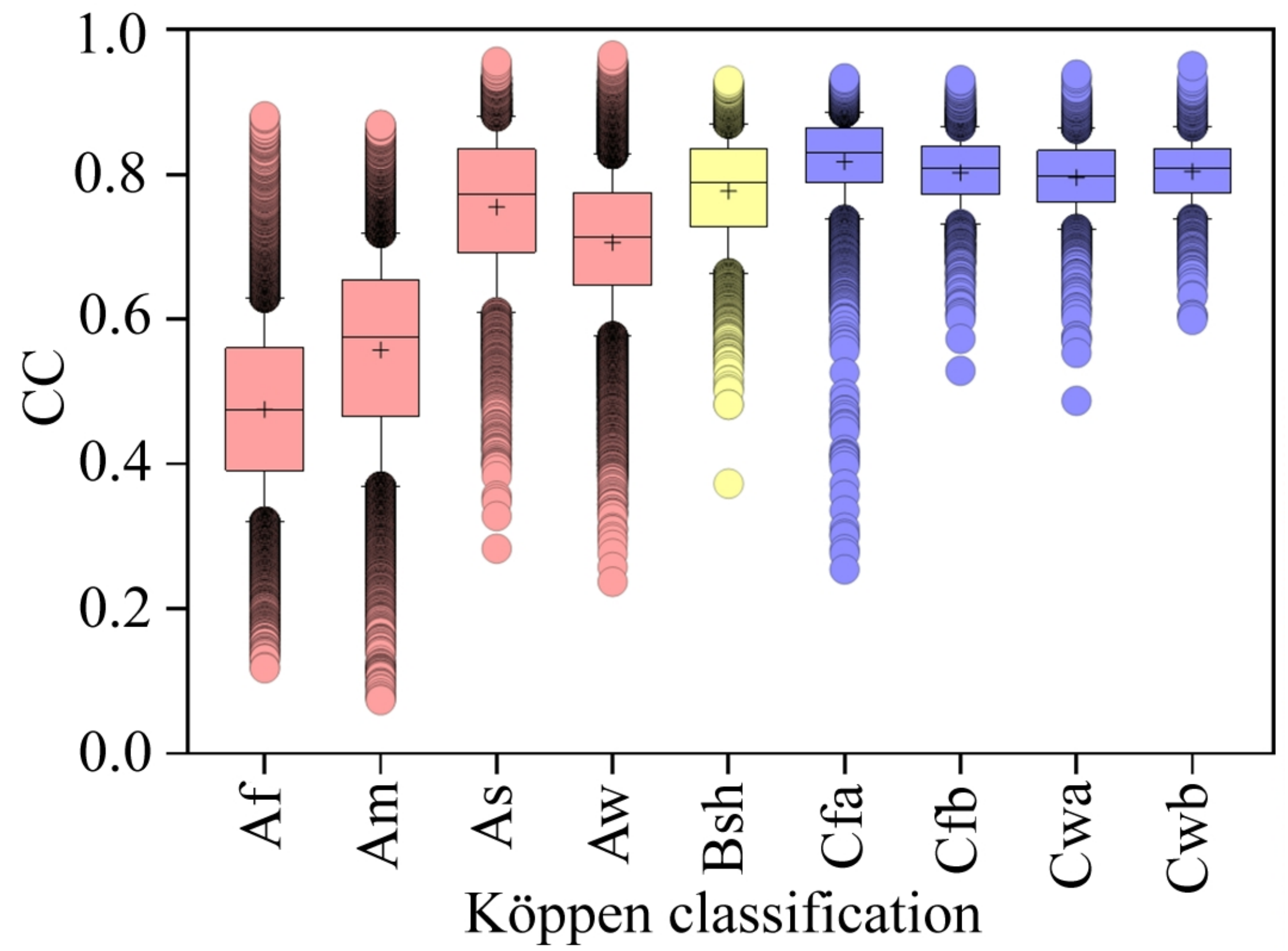


Table 1 Summary of relevant studies that evaluated the IMERG products at country-wide scale in relation to the proposed study.

\begin{tabular}{|c|c|c|c|c|c|}
\hline Study & IMERG Products & $\begin{array}{l}\text { Location / } \\
\text { study area }\end{array}$ & Study period & $\begin{array}{l}\text { Number of } \\
\text { gauges }\end{array}$ & $\begin{array}{r}\text { Analysis } \\
\text { approach }\end{array}$ \\
\hline 1. Tan and Duan (2017) & Final Run & $\begin{array}{l}\text { Singapore / } \\
719.9 \mathrm{k} \mathrm{km}^{2}\end{array}$ & $\begin{array}{l}\text { 1/Apr/2014 to } \\
31 / \operatorname{Jan} / 2016\end{array}$ & 48 & Point-cell \\
\hline 2. Muhammad et al. (2018) & $\begin{array}{l}\text { Late Run and Final } \\
\text { Run }\end{array}$ & $\begin{array}{l}\text { Pakistan / } \\
796.1 \mathrm{k} \mathrm{km}^{2}\end{array}$ & $\begin{array}{l}1 / \mathrm{Jan} / 2015 \text { to } \\
31 / 12 / 2016\end{array}$ & 36 & Point-cell \\
\hline 3. Mahmoud et al. (2018) & $\begin{array}{l}\text { Early Run, Late } \\
\text { Run, and Final Run }\end{array}$ & $\begin{array}{l}\text { Saudi Arabia / } \\
2.1 \mathrm{M} \mathrm{km}^{2}\end{array}$ & $\begin{array}{l}\text { 1/Oct/2015 to } \\
30 / \mathrm{Apr} / 2016\end{array}$ & 189 & Point-cell \\
\hline 4. Tang et al. (2016) & $\begin{array}{l}\text { Early Run, Late } \\
\text { Run, and Final Run }\end{array}$ & $\begin{array}{l}\text { China / } 9.3 \mathrm{M} \\
\mathrm{km}^{2}\end{array}$ & $\begin{array}{l}\text { 1/Apr/2014 to } \\
\text { 31/Dec/2014 }\end{array}$ & 2200 & Grid box \\
\hline 5. Prakash et al. (2018) & Final Run & $\begin{array}{l}\text { India / } 3.3 \mathrm{M} \\
\mathrm{km}^{2}\end{array}$ & $\begin{array}{l}\text { 1/Jun/2014 to } \\
31 / \operatorname{Sep} / 2014\end{array}$ & 7000 & Grid box \\
\hline 6. Tan and Santo (2018) & $\begin{array}{l}\text { Early Run, Late } \\
\text { Run, and Final Run }\end{array}$ & $\begin{array}{l}\text { Malaysia / } \\
338 \mathrm{k} \mathrm{km}^{2}\end{array}$ & $\begin{array}{l}\text { 12/Mar/2014 to } \\
29 / \mathrm{Feb} / 2016\end{array}$ & 501 & Point-cell \\
\hline 7. Rozante et al. (2018) & Final Run & $\begin{array}{l}\text { Brazil / } 8.5 \mathrm{M} \\
\mathrm{km}^{2}\end{array}$ & $\begin{array}{l}\text { 1/Apr/2014 to } \\
28 / \mathrm{Feb} / 2017\end{array}$ & 3400 & Point-cell \\
\hline 8. Asong et al. (2017) & Final Run & $\begin{array}{l}\text { Southern } \\
\text { Canada / } 6.1 \\
\mathrm{M} \mathrm{km} 2\end{array}$ & $\begin{array}{l}\text { 12/Mar/2014 to } \\
31 / \mathrm{Jan} / 2016\end{array}$ & $\begin{array}{l}732 \text { and } \mathrm{CaPA} \\
\text { gridded product }\end{array}$ & $\begin{array}{l}\text { Point-cell } \\
\text { and grid } \\
\text { box }\end{array}$ \\
\hline 9. This study & Final Run & $\begin{array}{l}\text { Brazil / } 8.5 \mathrm{M} \\
\mathrm{km}^{2}\end{array}$ & $\begin{array}{l}\text { 1/Jan/2016 to } \\
31 / \mathrm{Dec} / 2016\end{array}$ & 4911 & Grid box \\
\hline
\end{tabular}


Table 2 Definition of rainy and non-rainy days for IMERG-V05 and observed data.

\begin{tabular}{cccc}
\hline & & \multicolumn{2}{c}{ Gauge } \\
\cline { 3 - 4 } & & Rain & No rain \\
\hline \multirow{2}{*}{ IMERG-V05 } & Rain & $\mathrm{A}$ & $\mathrm{B}$ \\
& No rain & $\mathrm{C}$ & - \\
\hline
\end{tabular}


Supplementary material for

\section{Grid box-level evaluation of IMERG over Brazil at various space and time scales}

André N. Gadelha ${ }^{a,}$, Victor Hugo R. Coelho ${ }^{a,}{ }^{,}$, Alexandre C. Xavier ${ }^{b}$, Luís Romero Barbosaa,c, Davi C. D. Melo $^{\text {d,e }}$, Yunqing Xuan ${ }^{\mathrm{f}}$, George Huffman, Walt Petersen ${ }^{\mathrm{h}}$, Cristiano das N. Almeida ${ }^{\mathrm{a}}$

${ }^{a}$ Department of Civil and Environmental Engineering, Federal University of Paraíba, João Pessoa, PB 58051-900, Brazil

${ }^{\mathrm{b}}$ Department of Rural Engineering, Federal University of Espírito Santo, Alegre, ES 29075-910, Brazil

${ }^{c}$ Institute of Earth and Environmental Science, University of Potsdam, Potsdam, BB 14476, Germany

d Department of Soils and Rural Engineering, Federal University of Paraíba, Areia, PB 58397-000, Brazil

e Department Hydraulics and Sanitary Engineering, University of São Paulo, São Carlos, SP 13566-590, Brazil

${ }^{\mathrm{f}}$ College of Engineering, Swansea University, Bay Campus, Swansea SA1 8EN, UK

g NASA Goddard Space Flight Center, Greenbelt, MD 20771, USA

${ }^{\mathrm{h}}$ NASA Marshall Space Flight Center, Huntsville, AL 35805, USA

\section{Equations S1 (Relative ME) and S2 (Relative RMSE)}

The relative (R) errors for both ME and RMSE metrics are:

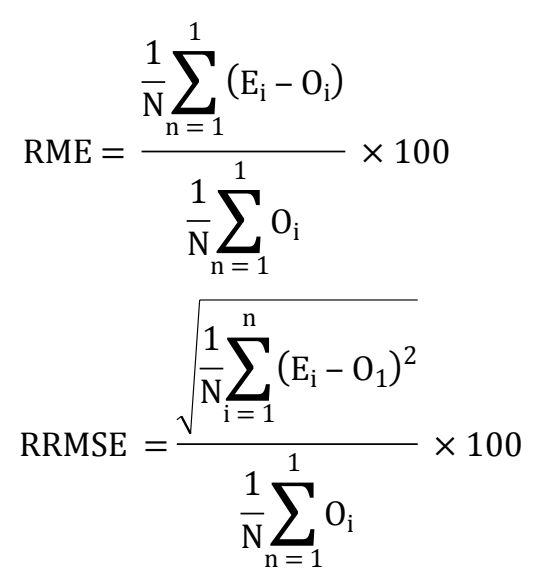

where $\mathrm{O}$ is the observed rainfall $(\mathrm{mm}), \mathrm{E}$ is the IMERG-V05 estimated rainfall $(\mathrm{mm}), \mathrm{i}$ is the index of the number of pairs, and $\mathrm{n}$ is the total number of compared pairs. Both relative ME and relative RMSE measure the precision of the IMERG-V05 product in relation to observed rainfall, so values close to zero percent 
indicate smaller deviations. However, the relative ME gives an overall indicator of the bias (positive or negative), with the disadvantage that the positive and negative errors can cancel each other. Hence, sometimes a small ME does not means minor errors. On the other hand, the relative RMSE gives an idea of estimate errors that is influenced by the sample size, tending to small results when increasing the $\mathrm{n}$.

\section{Figures S1 to S3}
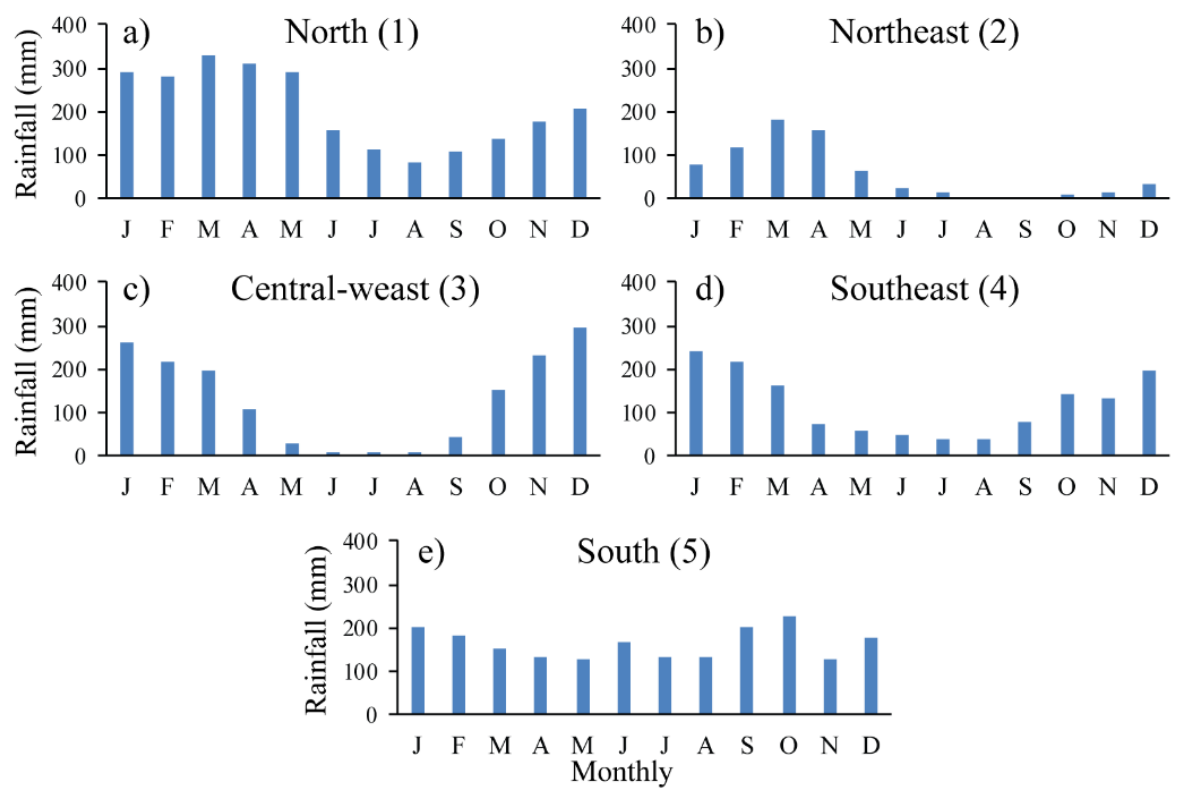

Fig. S1 Long-term monthly average rainfall obtained from rain gauges within the five selected subareas:

(a) North, (b) Northeast, (c) Central-west, (d) Southeast, and (e) South. 

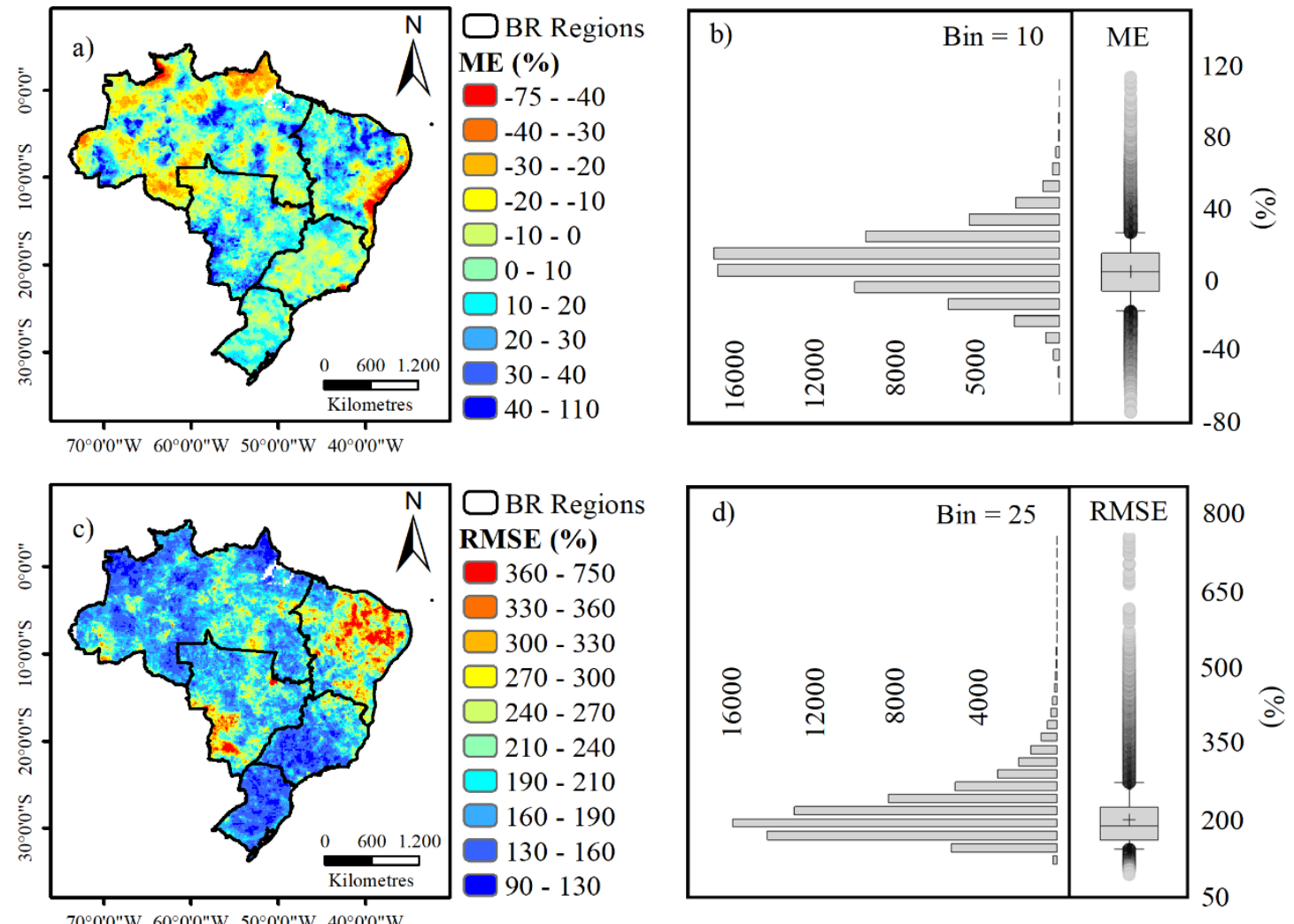

Fig. S2 Spatial distributions of daily relative (a) ME and (c) RMSE. Box plots and histograms of daily relative (b) ME and (d) RMSE.
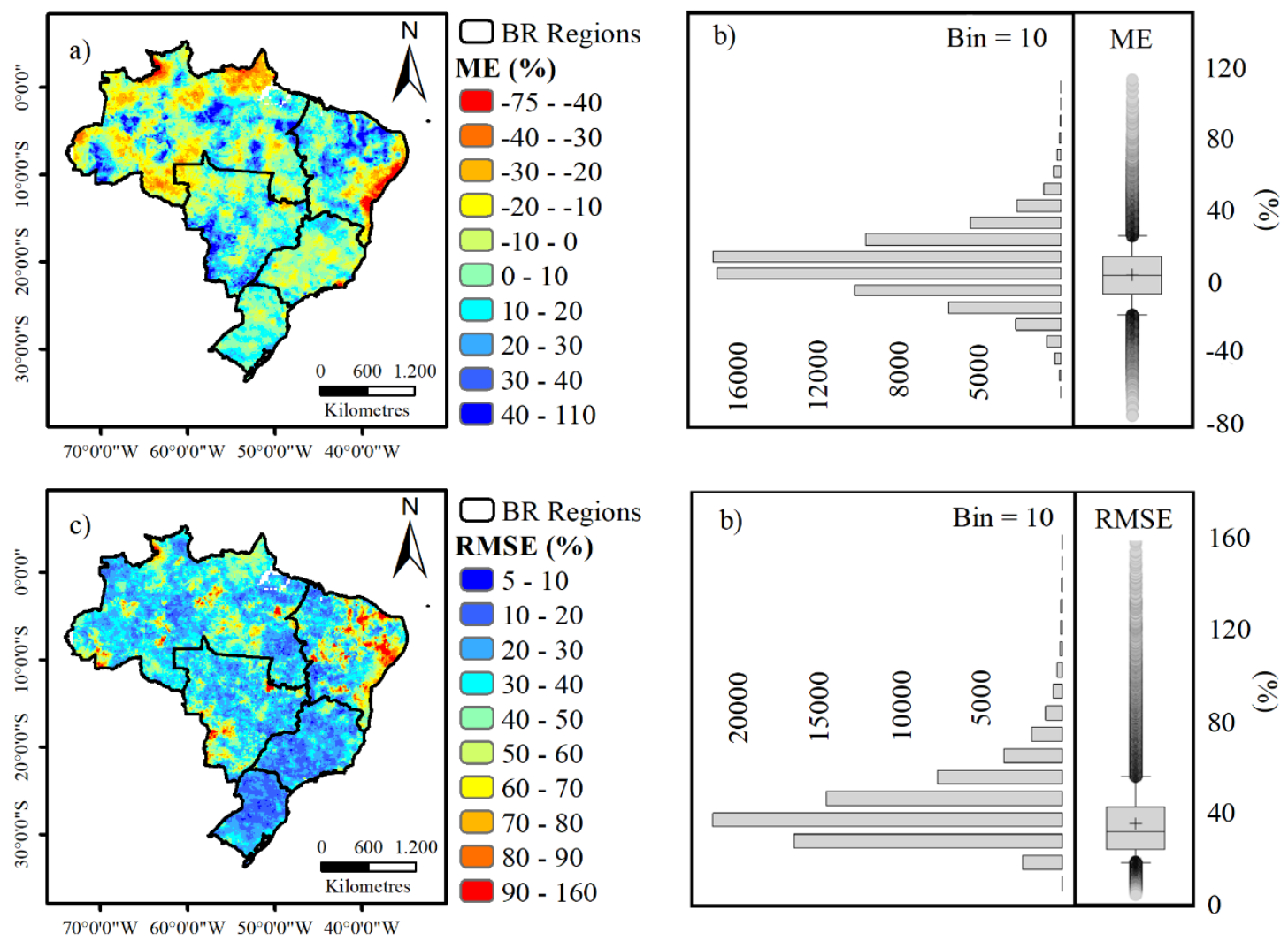
Fig. S3 Spatial distributions of monthly relative (a) ME and (c) RMSE. Box plots and histograms of monthly relative (b) ME and (d) RMSE.

\section{Table S1}

Table S1 Relative values of ME and RMSE for the subarea analysis at daily and monthly time scales.

\begin{tabular}{lllll}
\hline \multirow{2}{*}{ Region } & \multicolumn{3}{c}{ Daily } & \multicolumn{2}{c}{ Monthly } \\
\cline { 2 - 5 } & Relative ME & Relative RMSE & Relative ME & Relative RMSE \\
\hline North (1) & $7.4 \%$ & $93.9 \%$ & $7.4 \%$ & $11.6 \%$ \\
Northeast (2) & $32.3 \%$ & $196 \%$ & $32.2 \%$ & $47.4 \%$ \\
Central-west (3) & $6.0 \%$ & $88.1 \%$ & $6.0 \%$ & $13.6 \%$ \\
Southeast (4) & $1.3 \%$ & $96.5 \%$ & $1.3 \%$ & $8.7 \%$ \\
South (5) & $0.7 \%$ & $97.1 \%$ & $0.6 \%$ & $14.7 \%$ \\
\hline
\end{tabular}

